Escola Politécnica da Universidade de São Paulo

LUIS EDUARDO ABRANTES RUSSO

CONTRIBUIÇÃO AO PROCESSO DE AVALIAÇÃO TÉCNICA E SELEÇÃO DOS COMPONENTES DA GRADE FERROVIÁRIA PARA A IMPLANTAÇÃO EM FERROVIAS DE TRANSPORTE DE CARGA 
LUIS EDUARDO ABRANTES RUSSO

\section{CONTRIBUIÇÃO AO PROCESSO DE AVALIAÇÃO TÉCNICA E SELEÇÃO DOS COMPONENTES DA GRADE FERROVIÁRIA PARA A IMPLANTAÇÃO EM FERROVIAS DE TRANSPORTE DE CARGA}

Dissertação apresentada à Escola Politécnica da Universidade de São Paulo para obtenção do título de Mestre em Engenharia

Área de Concentração:

Engenharia de Transportes

Orientadora:

Prof $^{\text {a. }}$ Dr ${ }^{\text {a. }}$ Ana Paula Camargo Larocca

São Paulo 
Este exemplar foi revisado e alterado em relação à versão original, sob responsabilidade única do autor e com a anuência de seu orientador.

São Paulo, 09 de fevereiro de 2012.

Assinatura do autor

Assinatura do orientador Ina Paula b. Larocca

FICHA CATALOGRÁFICA

Russo, Luis Eduardo Abrantes

Contribuição ao processo de avaliação técnica e seleção dos componentes da grade ferroviária para a implantação em ferrovias de transporte de carga / L.E.A. Russo. -- ed.rev. -- São Paulo, 2012.

$86 \mathrm{p.}$

Dissertação (Mestrado) - Escola Politécnica da Universidade de São Paulo. Departamento de Engenharia de Transportes.

1. Ferrovias 2. Vias permanentes I. Universidade de São Paulo. Escola Politécnica. Departamento de Engenharia de Transportes II. t. 


\section{AGRADECIMENTOS}

À Prof ${ }^{a}$. Dr ${ }^{a}$. Ana Paula Camargo Larocca, minha orientadora e amiga, por todos os bons conselhos e revisões sempre cuidadosas dos textos que apresentei, além da confiança em mim depositada, pois acreditou nesta dissertação desde o primeiro momento.

Aos meus pais, em especial à minha mãe, por desde sempre cultivar e cobrar para que eu nunca deixasse de ter o hábito de estudar e jamais parasse de investir no prosseguimento de minha formação acadêmica. Certamente, este é o maior ensinamento que eu poderia receber, o qual carregarei comigo para sempre.

À minha namorada Carolina Sampieri Santinho, pela paciência e apoio durante os períodos mais difíceis da elaboração desta dissertação e, sobretudo, por fazer com que eu acreditasse sempre em meu potencial. O término deste trabalho é uma vitória, e certamente teremos muitas outras juntos daqui em diante.

Ao colega de trabalho e de mestrado, mas antes de tudo grande amigo pessoal, Pedro Henrique Stech, por todo o conhecimento, força e companheirismo compartilhados ao longo das disciplinas da pós-graduação e da elaboração desta dissertação. Amizades como essa são para toda a vida.

Ao Prof ${ }^{\circ}$. Dro‥ Ettore José Bottura, pelo incentivo dado ao meu ingresso no programa de pós-graduação e também à minha participação em congressos e outros encontros ferroviários.

Ao colega da Vetec Engenharia e amigo Edson Antônio Massicano, ao qual sou imensamente grato, por ajudar a desenvolver a idéia inicial do trabalho e, mais que isso, ser o responsável por minha entrada na área de projetos ferroviários, fato que certamente mudou o rumo de minha carreira profissional.

À Vetec Engenharia LTDA, empresa na qual trabalho, por apoiar meu ingresso no mestrado e permitir minha ausência do ambiente de trabalho para cursar as disciplinas da pós-graduação e elaborar esta dissertação.

Aos professores do Departamento de Engenharia de Transportes da Escola Politécnica da Universidade de São Paulo, por compartilhar tanto conhecimento 
técnico e experiência durante as disciplinas cursadas e em outras conversas fora da sala de aula.

Aos amigos do voleibol do CEPEUSP, por tantos bons momentos que somente a prática de atividade esportiva pode proporcionar.

Aos amigos e colegas de trabalho que, direta ou indiretamente, colaboraram nesta dissertação. 


\section{RESUMO}

Nos últimos anos, tem-se presenciado um contínuo aumento na demanda por transporte de carga ferroviário no Brasil, o que tem se refletido em maior volume de projetos para expansão ou revitalização da malha existente no país. Diante deste quadro atual, torna-se essencial que o profissional envolvido com a elaboração de projetos da via permanente tenha em mãos informações atualizadas a respeito da variedade de componentes da grade ferroviária existente no mercado, a fim de que os projetos atendam plenamente às necessidades do cliente.

Assim sendo, o presente trabalho tem como principal objetivo pesquisar e analisar os tipos de componentes existentes no mercado usados na composição da grade ferroviária (trilhos, dormentes e fixações), com foco principal naqueles que podem ser aplicados às ferrovias de transporte de carga. Primeiramente, a partir de pesquisa em material bibliográfico nacional e internacional, serão descritos os principais aspectos técnicos que devem ser considerados no processo de avaliação destes componentes, tendo como base os parâmetros de projeto da via estabelecidos previamente de acordo com as exigências da operação de carga, tais como: carga por eixo, velocidade de operação, rampa máxima, etc.

Em seguida, serão apresentados os tipos de trilhos, dormentes (madeira, concreto monobloco e bi-bloco, aço e plástico) e fixações (rígidas e elásticas) existentes atualmente no mercado e suas características de desempenho e condições de uso estabelecidas pelos respectivos fabricantes. Os dados obtidos nas duas etapas descritas anteriormente serão analisados e confrontados, de forma que seja possível explicitar as relações de interdependência que existem entre os diferentes tipos de componentes.

Ao final do trabalho, será apresentado um modelo de fluxograma que reúne os dados de entrada para o projeto da ferrovia de transporte de carga, as diretrizes técnicas que devem ser atendidas em seu projeto e, por fim, os tipos de componentes da grade ferroviária que podem ser empregados de acordo com o caso estudado. Com isso, espera-se que o produto final gerado possa ser uma ferramenta útil na etapa de concepção de novos projetos ferroviários, visto que 
apresentará de maneira clara e objetiva um conjunto de informações bastante abrangente e atualizado a respeito dos critérios técnicos e das opções de componentes disponíveis no mercado, fornecendo uma orientação inicial consistente ao profissional envolvido sobre os materiais que podem ser aplicados à via em estudo.

Palavras-Chave: Via Permanente; Grade Ferroviária; Ferrovias de Transporte de Carga; Avaliação Técnica dos Componentes. 


\begin{abstract}
Over the last years, a continuous increase on demand for railroad heavy haul transport has been witnessed in Brazil, reflecting in bigger volume of projects for expansion or improvement of the existing lines in the country. With this current situation, it becomes essential that the professional involved with the elaboration of projects of the permanent way should have information brought up to date regarding the variety of components of the existing railroad materials in the market, so that the projects take care of fully to the necessities of the customer.

Thus being, the present work has as main objective to search and to analyze the types of existing components in the market used in the composition of the railroad superstructure (rails, ties and fastenings), with main focus in that which can be applied to the heavy haul railways. First, from research in national and international bibliographical material, the main aspects related to the performance that must be considered in the process of evaluation of these components will be describes, having as base the design parameters of the way established previously in accordance with the requirements of the load operation, such as: position for axle, speed of operation, maximum slope, and others.
\end{abstract}

After that, the types of rails, ties (wood ties, monoblock and bi-block concrete ties, steel ties and plastic ties) and fastenings (rigid and elastic) currently available in the market and its characteristics of performance and conditions of use will be presented, according to the information provided by the its respective manufacturers. All the reports showed in the two previous described stages will be analyzed and compared, so that is possible to highlight the interdependence relations that exist between the different types of components.

At the end of the work, a flowchart model which gathers the input data about the heavy haul railrod, the performance guidelines that should be followed and the types of components of the railroad superstructure that can be used in accordance to the studied case, will be presented. With that, it is expected that the produced flowchart could be a useful tool in the stage of design of a new railroad, once it will present in a clear and objective way an embracing and up-to-date set of information regarding the 
performance criteria and the options of components available in the market, supplying a consistent initial orientation to the designer about the materials that could be applied to the railway.

Keywords: Permanent-Way; Track Structure; Heavy Haul Railway; Technical Evaluation of the Components. 


\section{Lista de Figuras}

Figura 1: Investimentos nas Malhas Existentes concedidas à Iniciativa Privada, entre 1997 e 2010 (R\$ Milhões)

Figura 2: Movimentação de Carga Transportada pelas Ferrovias (Milhões de TUs) 19

Figura 3: Comparativo do Transporte Ferroviário de Carga x PIB 19

Figura 4: Exemplo Esquemático - Vagão GDT. .23

Figura 5: Exemplo - Vagão Hopper HFE .23

Figura 6: Perfil do Trilho "Vignole" .25

Figura 7: Trilho TR68 (136RE no padrão AREMA) .25

Figura 8: Dormente de Madeira, em via operada pela MRS Logística S.A. .32

Figura 9: Dormente de Madeira Plástica .37

Figura 10: Dormente de Madeira Plástica em Via da MRS Logística S.A. .38

Figura 11: Dormente Protendido Monobloco. .40

Figura 12: Dormente Bi-Bloco com Fixação Elástica Aparafusada .42

Figura 13: Croqui llustrativo das 4 Faces de Apoio Lateral do Dormente Bi-bloco ...43

Figura 14: Dormente de Aço UIC 865-2 .45

Figura 15: Prego de Linha .52

Figura 16: Tirefond .53

Figura 17: Comparação Fixação DB2 e Fixação RN. .55

Figura 18: Fixação DB2 em um Dormente de Concreto Bi-Bloco .55

Figura 19: Fixação Aparafusada do tipo RN em linha operada pela ALL Logística...56

Figura 20: Modelo S.75 .57 
Figura 21: Fixação S.75 em Dormente de Concreto Bi-Bloco

Figura 22: Grampo Deenik de Seção Variável ............................................58

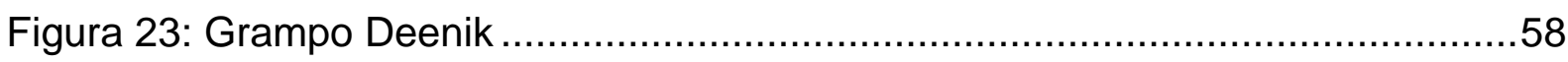

Figura 24: Aplicação do Grampo Deenik em na Ligação Ferroviária entre São Paulo

e Mato Grosso do Sul - ALL Logística 59

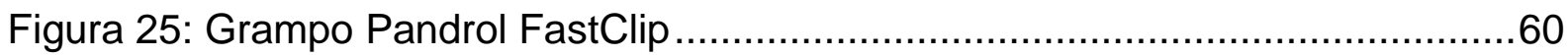

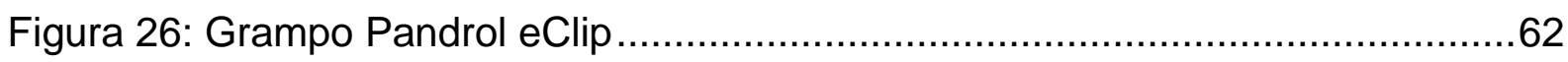

Figura 27: Características do Grampo Pandrol eClip ....................................63

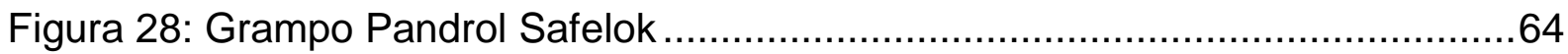

Figura 29: Modelo do Fluxograma Proposto - Parte 1 (continua na página seguinte)

Figura 30: Modelo do Fluxograma Proposto - Parte 2 (continuação) .......................68

Figura 31: Localização do Empreendimento ................................................... 70

Figura 32: Trecho entre as Estações da CPTM Eng. Manoel Feio e Calmon Viana $(8,2 \mathrm{~km})$ . .71

Figura 33: Trecho entre as Estações da CPTM Calmon Viana e Suzano $(3 \mathrm{~km}) \ldots . . . .72$ Figura 34: Via da CPTM Existente, com Dormentes de Madeira e Grampos Pandrol .73 


\section{Lista de Tabelas}

Tabela 1: Participação por Modal no Brasil

Tabela 2: Resumo dos Trens de Carga Característicos .22

Tabela 3: Tipos de Trilhos e Pesos Lineares .26

Tabela 4: Dimensões e Tolerâncias do Dormente de Madeira .33

Tabela 5: Propriedades Físicas das Madeiras, de acordo com o Grupo 33

Tabela 6: Dimensões dos Dormentes de Madeira Plástica 36

Tabela 7: Comparação entre os Esforços e Deslocamentos Longitudinais para os Dormentes Estudados .46

Tabela 8: Comparação entre os Esforços e Deslocamentos Transversais para os Dormentes Estudados

Tabela 9: Resumo das Características dos Dormentes .48

Tabela 10: Função das Fixações de Acordo com o Tipo de Dormente .50

Tabela 11: Características da Fixação Pandrol FastClip. .60

Tabela 12: Características da Fixação Pandrol eClip 62

Tabela 13: Características da Fixação Pandrol Safelok .64

Tabela 14: Resumo das Características dos Grampos Pandrol .65 


\section{Lista de Siglas}

ABNT Associação Brasileira de Normas Técnicas

AMV Aparelho de Mudança de Via

ANTF Associação Nacional dos Transportadores Ferroviários

ANTT Agência Nacional de Transportes Terrestres

AREMA American Railway Engineering and Maintenance-of-Way Association

CBTU Companhia Brasileira de Trens Urbanos

CPTM Companhia Paulista de Trens Metropolitano 


\section{Sumário}

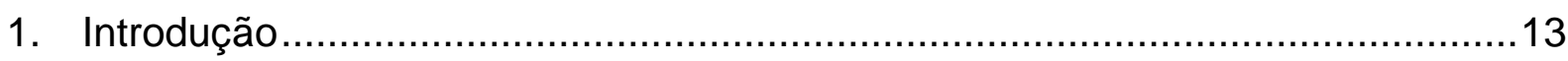

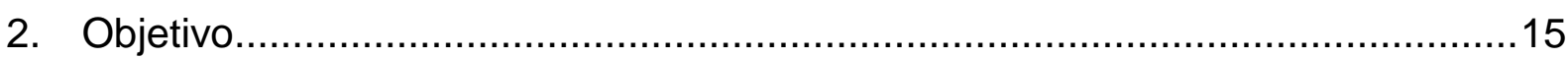

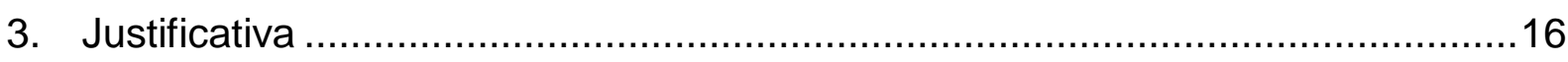

4. Ferrovias para o Transporte de Carga ......................................................... 17

4.1 Panorama Atual das Ferrovias de Transporte de Carga no Brasil ...............17

4.2 Principais Características e Requisitos de Projeto para as Ferrovias de

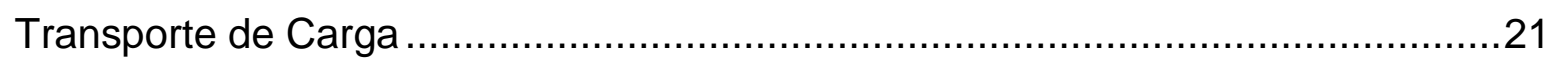

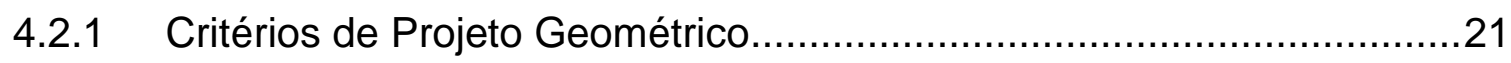

4.2.2 Características do Carregamento e do Material Rodante ......................22

5. Grade Ferroviária: Os Componentes e suas Principais Características .............24

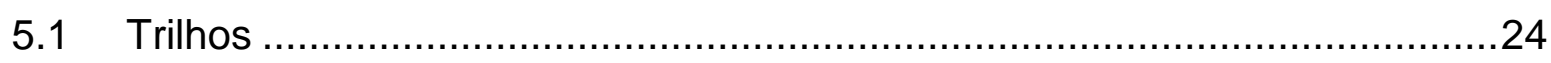

5.1.1 Dimensionamento do Perfil do Trilho ..............................................27

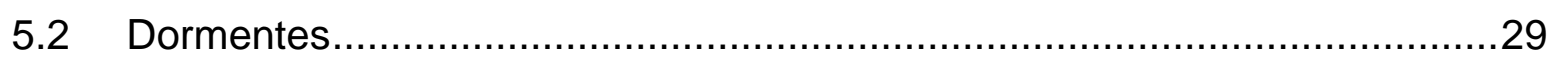

5.2.1 Dormente de Madeira ....................................................................

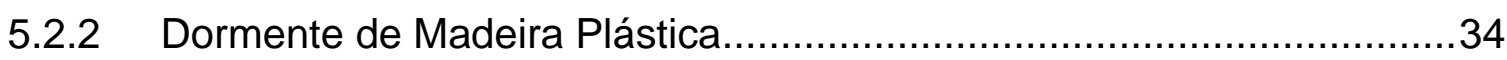

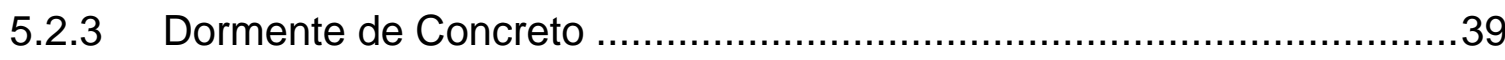

5.2.3.1 Dormente de Concreto Protendido Monobloco ..............................40

5.2.3.2 Dormente de Concreto Bi-Bloco.....................................................41

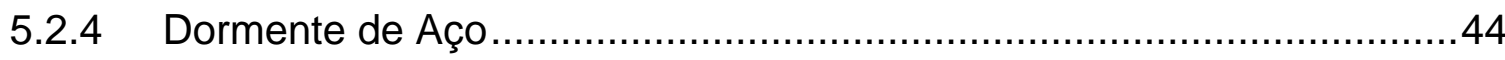

5.2.5 Análise Comparativa e Resumo das Características dos Dormentes....46

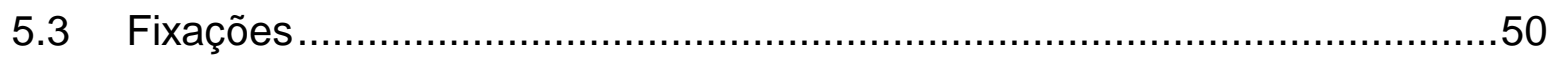

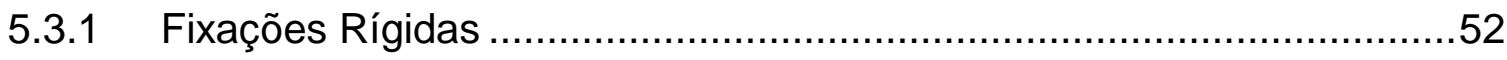

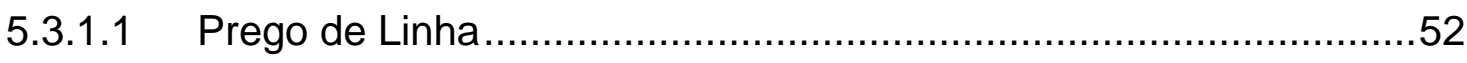

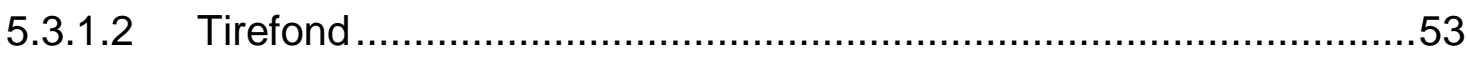


5.3.2.1 Fixação Aparafusada Dorbrás DB2 …………..............................54

5.3.2.2 Fixação Aparafusada Dorbrás S.75 ….........................................56

5.3.2.3 Grampo Elástico Deenik..........................................................58

5.3.2.4 Grampo Elástico Pandrol FastClip ..............................................59

5.3.2.5 Grampo Elástico Pandrol eClip ................................................61

5.3.2.6 Grampo Elástico Pandrol Safelok .............................................63

6. Modelo de Fluxograma para a Avaliação e Seleção dos Componentes da Grade

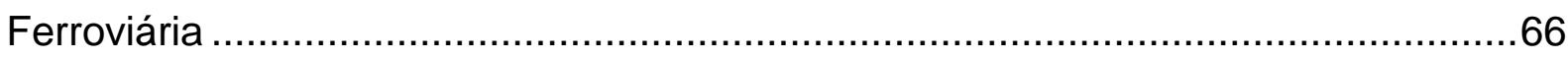

7. Estudo de Caso - Aplicação do Modelo de Fluxograma Proposto a uma Ferrovia

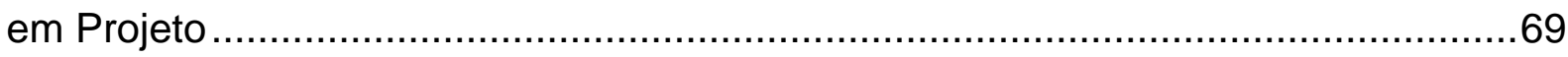

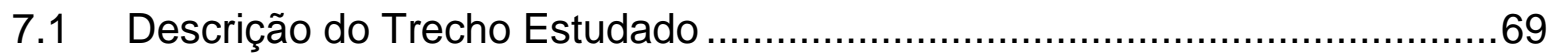

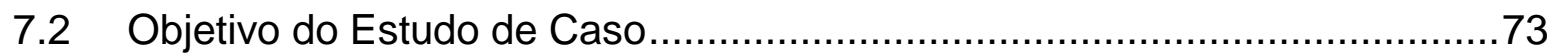

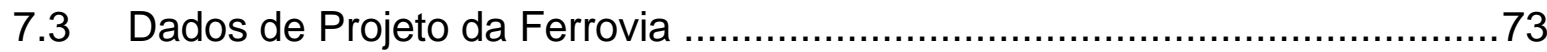

7.4 Aplicação do Fluxograma Proposto ao Projeto das Novas Vias para o Transporte de Carga e Discussão dos Resultados Obtidos...................................75

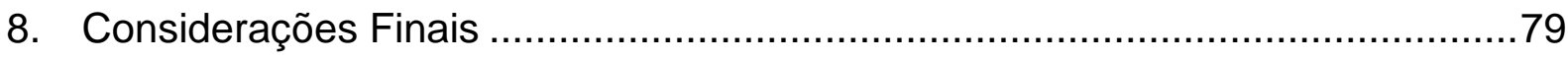

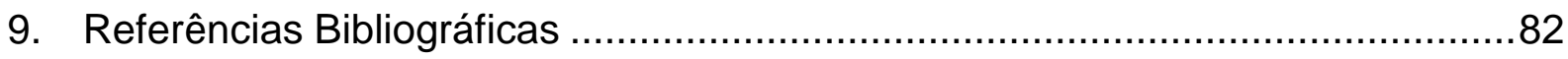




\section{Introdução}

Uma ferrovia, em linhas gerais, é composta por duas partes principais, a subestrutura e a superestrutura. A subestrutura corresponde aos trabalhos de drenagem e terraplanagem, construção civil, obras de arte, pontes, viadutos e túneis, estações e infra-estruturas de manutenção. Já a superestrutura corresponde, essencialmente, à via férrea e seus elementos permanentes, subestações de energia e linhas de alimentação, sistemas de sinalização e telecomunicações (STOPATTO, 1987).

O processo de definição do tipo de estrutura e materiais que compõem a via permanente de uma ferrovia varia de acordo com o caso que será estudado. Não é possível adotar um padrão fixo de tomada de decisão em relação aos materiais que serão empregados, visto que os condicionantes técnicos variam conforme a finalidade a qual a via se destina.

Basicamente, os principais aspectos dos elementos de via permanente a serem observados são: carga máxima por eixo prevista para a operação, velocidade de operação, vida útil de serviço, tipo e periodicidade de manutenção, condições locais (clima) e disponibilidade de materiais na região, principalmente para lastro e sublastro (ESVELD, 1989).

A escolha dos componentes da via permanente deve ser feita tendo como objetivo primordial atender, primeiramente, aos aspectos técnicos necessários ao adequado desempenho da ferrovia para a finalidade a qual seu projeto se propõe. Entretanto, algumas das exigências destes aspectos técnicos podem levar a decisões conflitantes - ex.: a opção pela instalação de um tipo de dormente que seja mais barato minimiza o custo de implantação. Porém, no caso de a sua manutenção ser mais freqüente ou o trabalho necessário para a substituição ser mais lento, pode acarretar em prejuízos à operação, devido à necessidade de interrupções do tráfego por períodos mais longos.

Desta forma, tornam-se importante, no decorrer deste processo de análise, que sejam bem definidos os aspectos técnicos a serem priorizados na avaliação dos 
componentes da grade ferroviária, além de procurar levar em conta também as particularidades que cada projeto apresenta (como restrições relativas à geometria, disponibilidade de materiais, etc), já que a correta seleção inicial dos materiais (mesmo que resulte mais onerosa) pode perfeitamente ser revertida em menores despesas com manutenção e substituição de componentes ao longo da vida útil da linha férrea. (ESVELD, 1989). 


\section{Objetivo}

O presente trabalho tem como principal objetivo apresentar os tipos de trilhos, dormentes e fixações disponíveis no mercado brasileiro aplicáveis às ferrovias de transporte de carga e analisá-los conforme os requisitos de desempenho aos quais estes materiais devem atender, a partir da consulta a normas técnicas e recomendações de projeto nacionais e internacionais, a fabricantes dos componentes e às concessionárias operadoras de vias de transporte de carga. Ao final do trabalho, será apresentado um modelo de fluxograma que reunirá os dados de entrada necessários para o projeto de uma ferrovia de transporte de carga, os principais requisitos técnicos que devem ser avaliados para cada componente da grade ferroviária e os materiais que podem ser empregados, de acordo com cada caso estudado. Desta maneira, espera-se que o banco de dados apresentado e o fluxograma produzido sirvam como orientação inicial para o processo de tomada de decisão sobre os componentes que podem vir a ser usados na implantação de uma nova linha ou mesmo na recuperação/readequação de uma linha já existente, visando proporcionar a escolha dos materiais que melhor atendam às exigências de projeto. 


\section{Justificativa}

A escolha do tema para esta pesquisa foi motivada pela escassez de material bibliográfico atualizado (livros, manuais e instruções de projeto) relativo à variedade de componentes da superestrutura da via permanente existente no mercado brasileiro.

Percebe-se claramente, ao se trabalhar em projetos ferroviários, que existe enorme dificuldade na obtenção de informações técnicas referentes aos elementos da via permanente. Ao se elaborar um projeto de implantação ou revitalização de uma linha férrea, há poucas referências das quais seja possível extrair dados concretos a respeito do uso de determinado material - por exemplo, qual elemento de fixação pode apresentar melhor desempenho em uma via para transporte de carga elevada, como minério de ferro. Diante deste fato, muitas vezes a decisão sobre o emprego dos materiais acaba sendo tomada com base em critérios empíricos ou em experiências anteriores já vivenciadas pelo profissional envolvido, visto que não se consegue proceder a uma análise técnica e comparativa dos diferentes tipos de elementos existentes. 


\section{Ferrovias para o Transporte de Carga}

\subsection{Panorama Atual das Ferrovias de Transporte de Carga no Brasil}

O transporte de cargas ferroviário, no Brasil, é caracterizado por possuir um custo fixo bastante elevado, em razão dos altos valores envolvidos no arrendamento da malha e de terminais e na aquisição e manutenção da via e do material rodante. Em contrapartida, os custos variáveis - mão-de-obra, combustível e energia - são relativamente baixos, o que justifica o uso do trem para o transporte de mercadorias de baixo valor agregado e de grande volume .

Para que os elevados custos fixos possam ser diluídos, a fim de tornar este meio de transporte competitivo, é necessário que a malha desenvolva uma infra-estrutura eficiente, através de vias que suportem a crescente carga por eixo dos vagões e que sejam providas de sinalização e superestrutura adequadas.

No caso brasileiro, o retorno dos investimentos e o início da modernização na malha só começaram com o processo de desestatização, na década de 1990. A Figura 1, a seguir, representa o crescimento dos investimentos na malha ferroviária após as concessões, onde se nota que o investimento das empresas do setor privado totaliza quase $R \$ 24$ bilhões, no período entre 1997 e 2010, o qual é um valor significativamente maior que aquele despendido pela União, no mesmo período. 


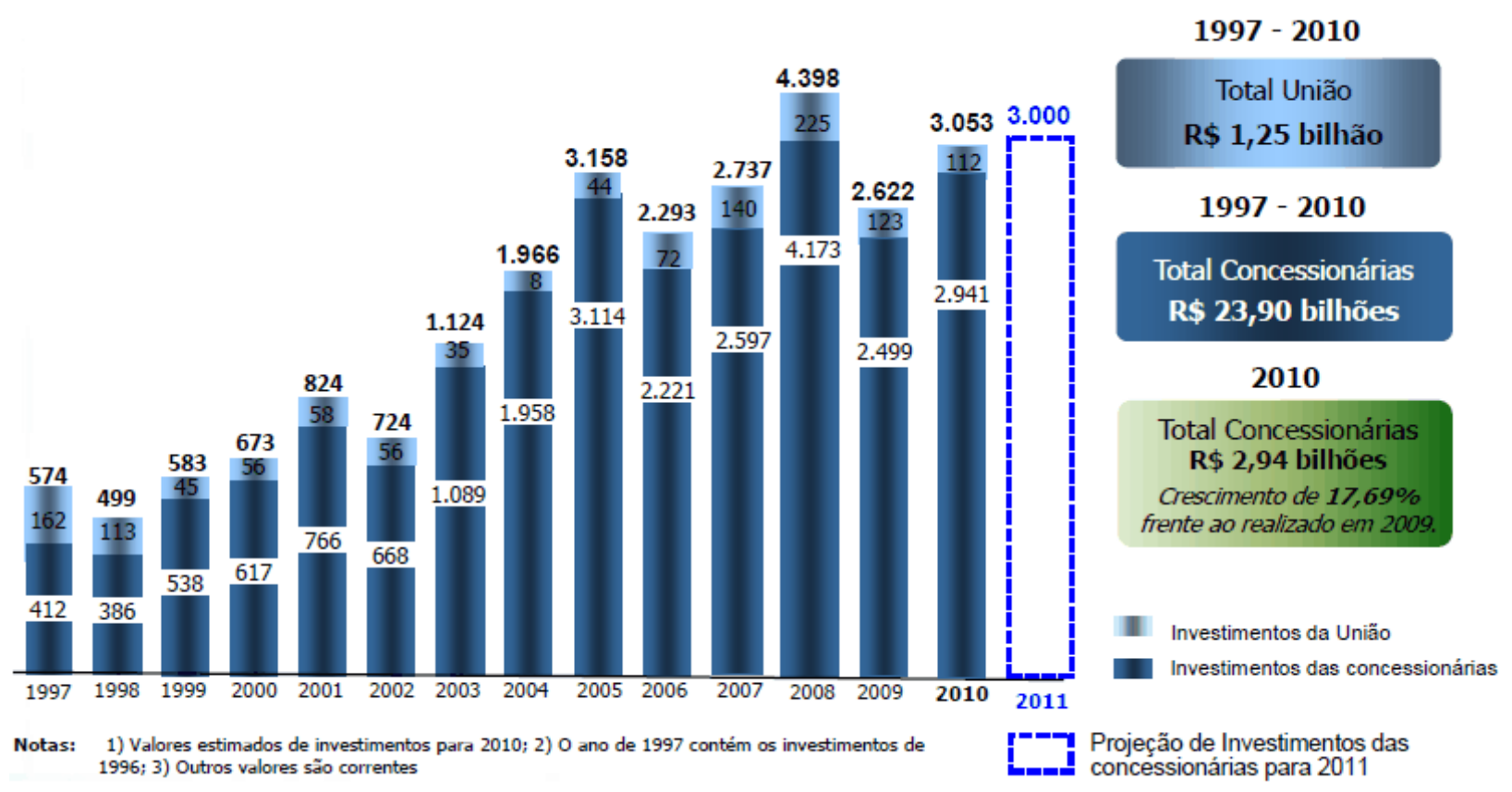

Figura 1: Investimentos nas Malhas Existentes concedidas à Iniciativa Privada, entre 1997 e 2010 (R\$ Milhões)

FONTE: Balanço do Transporte Ferroviário de Cargas - Associação Nacional dos Transportadores

Ferroviários (ANTF), 2010 (adaptado pelo autor)

Desde então, como conseqüência natural da elevação dos investimentos na melhoria da malha, tem havido um aumento expressivo no volume de mercadorias transportadas pelo modo ferroviário. Para o ano de 2011, é estimada uma movimentação de carga pelas concessionárias de 530,0 milhões de TUs (toneladas úteis), o que representa um aumento de quase 13\% em relação ao ano anterior (Figura 2).

Em razão do crescimento do volume de mercadorias transportadas, as receitas geradas por este modo também tem aumentado continuamente após a desestatização, inclusive com números acima da economia nacional. Conforme ilustra a Figura 3, no período entre 1997 e 2010, a produção do transporte ferroviário cresceu $103 \%$, enquanto que a economia brasileira teve aumento de $47,8 \%$ no seu PIB, durante o mesmo período. 


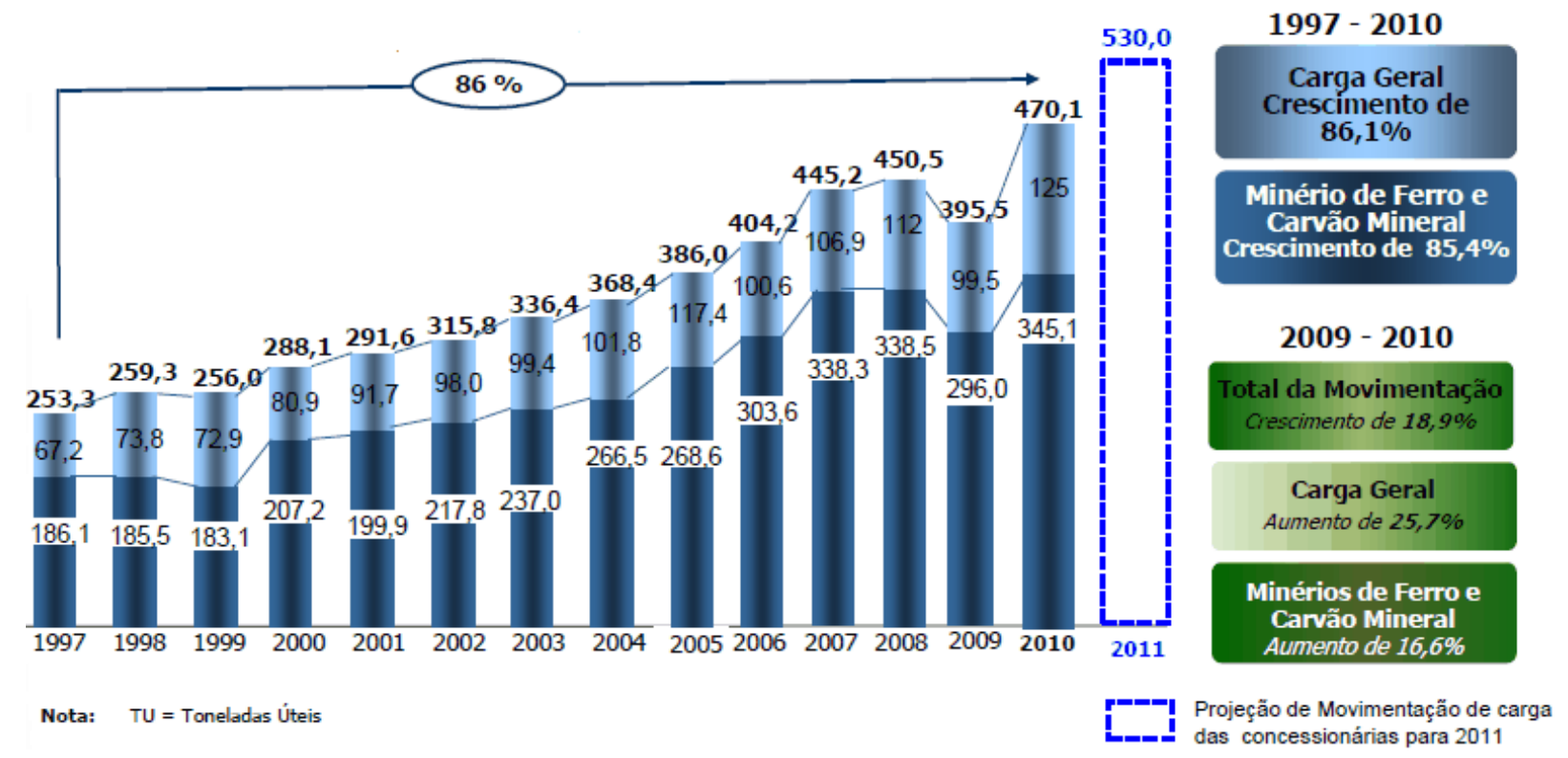

Figura 2: Movimentação de Carga Transportada pelas Ferrovias (Milhões de TUs)

FONTE: Balanço do Transporte Ferroviário de Cargas - Associação Nacional dos Transportadores

Ferroviários (ANTF), 2010 (adaptado pelo autor)

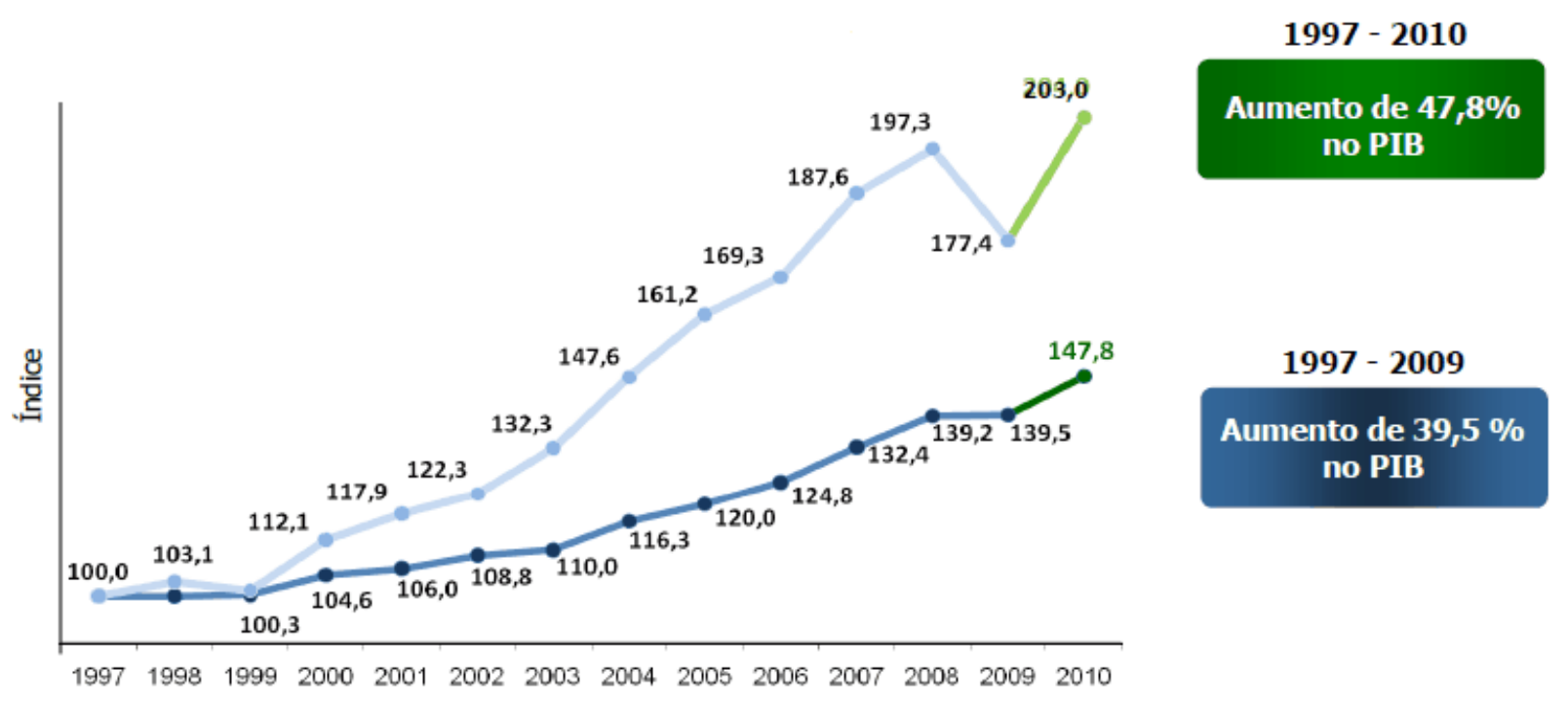

Nota: Índice base 100,00 em 1997.

Figura 3: Comparativo do Transporte Ferroviário de Carga x PIB

FONTE: Balanço do Transporte Ferroviário de Cargas - Associação Nacional dos Transportadores

Ferroviários (ANTF), 2010 (adaptado pelo autor) 
Porém, mesmo com o investimento e o aumento contínuo da movimentação de cargas por ferrovias verificados a partir de 1997, a matriz de transportes nacional ainda é amplamente dominada pelo modo rodoviário, como se observa na Tabela 1.

Tabela 1: Participação por Modal no Brasil

\begin{tabular}{ccc}
\hline Modal & Milhões (TKU) & Participação (\%) \\
\hline Rodoviário & 465.525 & 61,1 \\
Ferroviário & 164.809 & 20,7 \\
Aquaviário & 108.000 & 13,6 \\
Dutoviário & 33.300 & 4,2 \\
Aéreo & 3.169 & 0,4 \\
\hline Total & 774.803 & 100 \\
\hline
\end{tabular}

FONTE: Agência Nacional de Transportes Terrestres (ANTT), 2007

Diante dos dados apresentados acima, nota-se que o setor de transporte ferroviário tem apresentado uma evolução constante em sua capacidade ao longo dos últimos anos no Brasil, e para que este crescimento possa ter continuidade é fundamental o investimento em melhorias na infra-estrutura da malha. Estas melhorias, por sua vez, estão diretamente relacionadas à qualidade e à adequação dos componentes da superestrutura conforme as necessidades de cada tipo de via (nova ou revitalizada), o que demonstra a importância do conhecimento destes materiais - em especial dos trilhos, dormentes e fixações - e de suas principais características e requisitos de desempenho. 


\subsection{Principais Características e Requisitos de Projeto para as Ferrovias de Transporte de Carga}

As ferrovias de uso exclusivo para o transporte de carga apresentam características para a definição do traçado e de seus componentes da superestrutura muito mais restritivas que as ferrovias de transporte de passageiros, devido a fatores como: cargas por eixo mais elevadas, menores velocidades operacionais, menores inclinações de rampas máximas e atendimento à grande variedade de vagões que podem trafegar na via.

Os requisitos técnicos que devem ser avaliados em projeto podem ser divididos em dois grupos distintos: critérios de projeto geométrico da via permanente e características do carregamento e do material rodante.

\subsubsection{Critérios de Projeto Geométrico}

As ferrovias voltadas ao transporte de carga possuem padrões de velocidades de operação mais baixos que as vias convencionais, principalmente em razão da grande extensão das composições e das elevadas cargas contidas nos vagões.

Em resumo, as principais características limitantes para o projeto geométrico, obtidas a partir de dados da concessionária MRS Logística S.A. e da Valec Engenharia, Construções e Ferrovias S.A., podem ser definidas da seguinte forma:

a) Tipo de bitola:

Influencia o valor dos raios mínimos horizontais de curvas. Pode ser métrica $(1,000 \mathrm{~m})$, larga $(1,600 \mathrm{~m})$ ou padrão $(1,435 \mathrm{~m})$.

b) Rampa Geométrica Máxima:

Deve ter inclinações máximas reduzidas, a fim de evitar o desgaste excessivo dos trilhos e reduzir os esforços de tração da locomotiva em trechos ascendentes e de frenagem nos trechos descendentes. $O$ valor máximo, segundo a MRS Logística S.A., não deve ultrapassar 1,5\%. 
c) Raio Horizontal Mínimo:

Também está relacionado à prevenção do desgaste excessivo dos trilhos e da roda do veículo, bem como à transmissão de menores esforços a todos os componentes da grade ferroviária e ao lastro. Como regra geral, o valor não deve ser menor que $300 \mathrm{~m}$.

d) Velocidade Máxima de Projeto:

Os valores normalmente variam entre $50 \mathrm{~km} / \mathrm{h}$ e $80 \mathrm{~km} / \mathrm{h}$, dependendo da carga transportada e das condições da via e do entorno. Para a definição da velocidade máxima operacional, o valor de projeto máximo é reduzido em 5 $\mathrm{km} / \mathrm{h}$.

\subsubsection{Características do Carregamento e do Material Rodante}

Ao contrário das ferrovias destinadas ao transporte de passageiros, onde o tipo de material rodante e os carregamentos na via pouco variam, as ferrovias de transporte de carga podem apresentar diversas combinações de locomotivas, vagões e tipo de carga. Estas combinações, denominadas trens característicos, serão separadas em cinco grupos distintos, que representam uma expressiva parcela dos tipos de carregamentos presentes nas ferrovias brasileiras. A Tabela 2 , a seguir, resume as características dos cinco grupos, obtidas a partir de dados da operadora MRS Logística S.A.

Tabela 2: Resumo dos Trens de Carga Característicos

\begin{tabular}{|c|c|c|c|c|}
\hline $\begin{array}{c}\text { Tipo de } \\
\text { Carga }\end{array}$ & $\begin{array}{c}\text { № } \\
\text { Locos }\end{array}$ & $\begin{array}{c}\text { № } \\
\text { Vagões }\end{array}$ & $\begin{array}{l}\text { Tipo de } \\
\text { Vagão }\end{array}$ & $\begin{array}{c}\text { Carga Total } \\
\text { (ton./ano) }\end{array}$ \\
\hline $\begin{array}{l}\text { Minério de } \\
\text { Ferro }\end{array}$ & 3 & 132 & $\begin{array}{c}\text { Gôndola } \\
\text { (GDT, GDU) }\end{array}$ & $11 \times 10^{6}$ \\
\hline Bauxita & 2 & 70 & $\begin{array}{c}\text { Gôndola } \\
\text { (GDT, GDU) }\end{array}$ & $2,3 \times 10^{6}$ \\
\hline $\begin{array}{l}\text { Siderúrgico } \\
\text { (bobinas, etc) }\end{array}$ & 2 & 60 & Plataforma & $4,0 \times 10^{6}$ \\
\hline $\begin{array}{c}\text { Cimento e } \\
\text { Areia }\end{array}$ & 2 & 70 & Tanque (TPS) & $4,0 \times 10^{6}$ \\
\hline Soja e Açúcar & 4 & 85 & $\begin{array}{l}\text { Hopper (HFT, } \\
\text { HFE) ou FFF }\end{array}$ & $8,0 \times 10^{6}$ \\
\hline
\end{tabular}

FONTE: MRS Logística S.A., 2010 (adaptado pelo autor) 


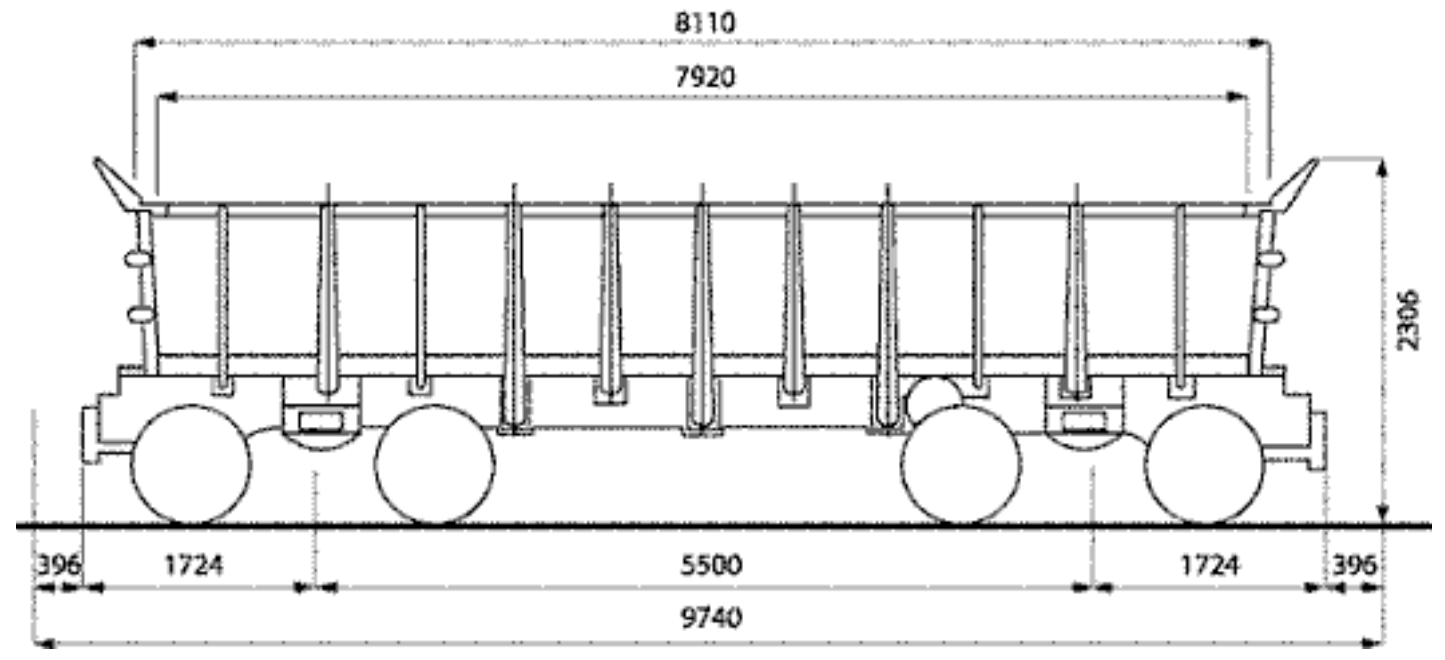

Figura 4: Exemplo Esquemático - Vagão GDT

FONTE: Amsted-Maxiom, 2011

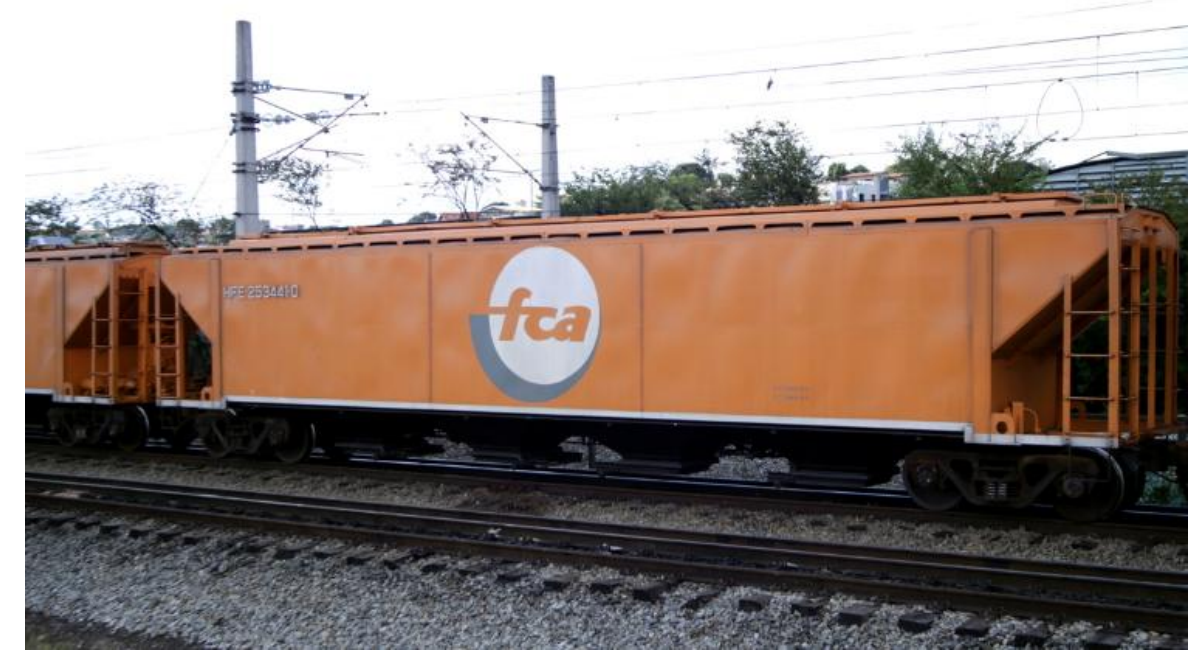

Figura 5: Exemplo - Vagão Hopper HFE

FONTE: Amsted-Maxiom, 2011

O conhecimento do material rodante e a determinação, dentre os diversos trens característicos possíveis, daquele que proporciona a situação de carregamento mais desfavorável à via, é fundamental para o correto pré-dimensionamento do perfil de trilho a implantar, conforme será demonstrado na seqüência do trabalho. 


\section{Grade Ferroviária: Os Componentes e suas Principais Características}

A via permanente ferroviária é constituída por três elementos principais: lastro, fixação, dormente e trilhos. Ela está sujeita à ação de desgaste das rodas dos veículos e do meio (intempérie) e é construída de modo a ser renovada, quando o seu desgaste atingir o limite de tolerância exigido pela segurança ou comodidade de circulação. (BRINA, 1979).

Aparentemente, pode ser considerada uma estrutura simples, devido à pequena quantidade de materiais que a compõe. No entanto, conforme será relatado a seguir, a grande variedade de componentes disponíveis no mercado e as relações de dependência existentes entre eles tornam o processo de avaliação e seleção destes materiais bastante complexo.

No presente trabalho, são analisados os tipos existentes, as características e os critérios técnicos a serem considerados na seleção dos seguintes componentes da superestrutura ferroviária: trilhos, dormentes e fixações.

\subsection{Trilhos}

O trilho é o componente mais importante da via permanente ferroviária, pois tem duas funções essenciais para o funcionamento da via (BRINA, 1979):

a) constitui a superfície de rolamento por onde trafega o veículo ferroviário, servindo como guia;

b) é a peça que recebe diretamente o carregamento produzido pelo movimento do veículo, além de ser responsável por transferir de maneira apropriada esses esforços para os demais elementos da superestrutura e da infraestrutura. 
Para que consiga desempenhar essas funções de maneira eficiente, é preciso que o trilho tenha dureza, tenacidade, elasticidade e resistência à flexão, características que são encontradas no aço.

O perfil adotado para os trilhos ferroviários convencionais é o "Vignole", composto por patim, alma e boleto, conforme indicam a Figura 6 e a Figura 7 , a seguir.

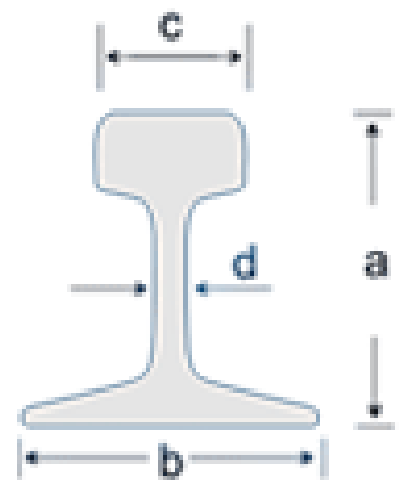

Figura 6: Perfil do Trilho "Vignole"

FONTE: AREMA Manual for Railway Engineering, 2009

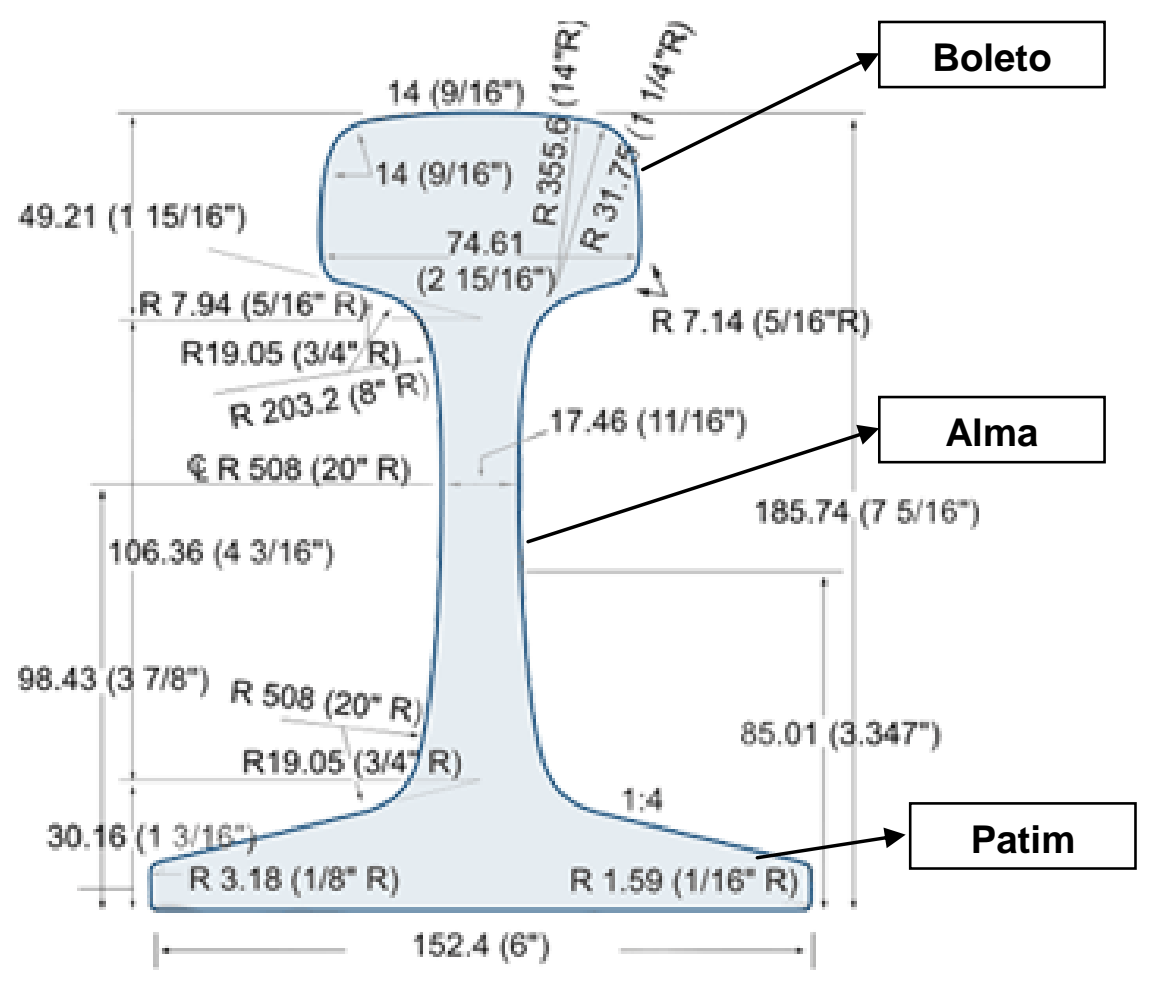

Figura 7: Trilho TR68 (136RE no padrão AREMA)

FONTE: AREMA Manual for Railway Engineering, 2009 (adaptado pelo autor) 
Os trilhos fabricados no Brasil, apresentados na Tabela 3, abaixo, são classificados conforme seu peso por metro linear e seguem os padrões da AREMA (American Railway Engineering and Maintenance-of-Way Association).

Tabela 3: Tipos de Trilhos e Pesos Lineares

\begin{tabular}{ccc}
\hline $\begin{array}{c}\text { Denominação no } \\
\text { Brasil }\end{array}$ & $\begin{array}{c}\text { Correspondente } \\
\text { Americano }\end{array}$ & Peso (kg/m) \\
\hline TR45 & ASCE 9020 & 44,6 \\
TR50 & 100RE - AREMA & 50,3 \\
TR57 & 115RE - AREMA & 56,7 \\
TR68 & 136RE - AREMA & 67,6 \\
\hline
\end{tabular}

FONTE: AREMA Manual for Railway Engineering, 2009 (adaptado pelo autor)

Para as ferrovias de transporte de carga, onde as solicitações são mais elevadas, normalmente os trilhos empregados são os modelos TR-57 e TR-68, ou o modelo UIC-60, que segue o padrão europeu de classificação.

A AREMA ainda estabelece critérios para a seleção do perfil do trilho com base em considerações relativas à estrutura da via permanente e aos custos durante o ciclo de vida deste componente.

Quanto aos aspectos estruturais, podem ser relacionados os requisitos a seguir:

a) O peso mínimo por metro linear deve ser suficiente para suportar os esforços dinâmicos atuantes no trilho provenientes do carregamento, das condições da via, da velocidade, das irregularidades no alinhamento superficial da via e da não uniformidade na camada de suporte (lastro e sublastro);

b) Os dormentes e demais componentes da superestrutura devem ter elasticidade suficiente para absorver os esforços transmitidos pelo trilho, a fim de evitar a concentração de tensões neste componente e, conseqüentemente, o surgimento de falhas (fissuras ou até mesmo a ruptura) no trilho ou no material rodante.

c) A resistência do perfil do trilho deve ainda ser avaliada segundo as condições do alinhamento vertical da via, da variação anual de temperatura e das variações relativas à operação, tais como: velocidade, carga máxima por eixo, tipos de trens e carregamento anual. 
Com relação aos aspectos referentes aos custos durante o ciclo de vida do trilho, são considerados todos os fatores que afetam a via economicamente, sendo que aqueles relacionados às variações produzidas por mudanças no espaçamento dos dormentes e custos de manutenção devem ser avaliados em diversos cenários diferentes. $\mathrm{O}$ objetivo da análise sob cenários distintos é observar em quais deles o valor final dos custos ao longo do tempo fornece como resultado um mesmo perfil de trilho a adotar, o qual será, assim, o mais econômico.

\subsubsection{Dimensionamento do Perfil do Trilho}

Dos diversos métodos existentes que permitem o pré-dimensionamento do perfil do trilho a ser implantado em uma ferrovia, optou-se, no presente trabalho, pela adoção do procedimento traduzido pela fórmula de SHAJUNIANZ (OLIVEROS RIVES, 1977). Esta formulação, embora empírica, consegue refletir com precisão satisfatória os resultados reais, pois seu cálculo engloba os principais fatores de solicitação, como: a carga anual, a velocidade máxima de projeto e a carga estática por eixo. A expressão tem validade para os casos onde a velocidade máxima de projeto da via seja igual ou inferior a $160 \mathrm{~km} / \mathrm{h}$ e é dada por:

$$
\mathrm{W}=\mathrm{k} \times\left(1+\mathrm{T}^{0,25}\right) \times(1+0,012 \times \mathrm{V})^{0,6667} \times \mathrm{Q}_{\mathrm{e}^{0,6667}}
$$

Onde:

W: Peso Linear do Trilho (em $\mathrm{kgf} / \mathrm{m})$;

k: Fator devido ao Material Rodante: adota-se o valor de $\mathrm{k}=1,20$ caso $\circ$ material rodante considerado sejam os vagões, ou $k=1,13$ se forem as locomotivas;

T: Tonelagem Bruta Anual (em $10^{6}$ ton./ano, com projeção para o horizonte de projeto): é importante que o valor a ser considerado neste item leve em consideração alguma previsão anual de aumento da carga transportada - ex.: 1,5\% de aumento do volume transportado ao ano - dentro do horizonte do projeto; V: Velocidade Máxima de Projeto (em $\mathrm{km} / \mathrm{h}$ ); 
$\mathrm{Q}_{\mathrm{e}}$ : Carga Estática por Eixo (em $\mathrm{kN}$ ou tf): representa o valor máximo da carga vertical estática suportada por um único eixo da locomotiva, do vagão de carga ou do carro de passageiros (o maior valor deve ser adotado), considerando-se o trem carregado na sua capacidade máxima, porém sem incremento dinâmico.

O resultado obtido, com a aplicação dos dados iniciais de projeto da ferrovia à Equação (1), indica o peso linear mínimo que o perfil do trilho a ser implantado deve possuir, a fim de que atenda às condições do carregamento inicial e também às solicitações futuras previstas.

Caso o perfil escolhido seja aquele que atenda apenas à tonelagem bruta anual inicial, há uma grande possibilidade de que este perfil precise ser substituído em um futuro muito próximo, se a demanda por transporte na ferrovia em questão tiver aumento. Neste cenário, a substituição do perfil adotado inicialmente trará um enorme custo adicional à ferrovia, pois, além de substituir um material que provavelmente ainda se encontrará longe do final de sua vida útil, haverá grande prejuízo com a improdutividade gerada pela parada das operações de transporte para a manutenção e troca deste componente ao longo de toda a via.

Uma vez definido o tipo de trilho que será implantado na via em projeto, é necessário verificar a sua capacidade de suporte das cargas induzidas pelo tráfego dos veículos ferroviários. A verificação compreende três itens:

a) Tensão Admissível à Flexão;

b) Tensão Admissível à Flexão na Face Inferior do Patim;

c) Deformação Máxima.

Sabendo-se que quase a totalidade das ferrovias destinadas ao transporte de carga no Brasil adota os parâmetros de projeto norte-americanos, passa a ser fundamental ter o conhecimento da metodologia de cálculo adotada como referência neste país.

Para os trilhos longos continuamente soldados, a AREMA (Manual for Railway Engineering, 2009) estabelece inicialmente a tensão admissível à flexão segundo os seguintes parâmetros máximos:

a) Flexão lateral: $20 \%$; 
b) Desgaste do trilho e corrosão: $15 \%$;

c) Superelevação não compensada máxima: 15\%;

d) Esforços devido à variação térmica: 96,7 MPa;

e) Tensão de escoamento do aço: 487,5 MPa.

O procedimento completo definido pela AREMA para a verificação do momento fletor máximo, tensão admissível à flexão e deformação máxima nos trilhos pode ser consultado na publicação "Manual for Railway Engineering - Chapter 4 - Rail", cuja última atualização data de 2009.

\subsection{Dormentes}

O dormente é o elemento da superestrutura ferroviária responsável por receber e transmitir ao lastro os esforços produzidos pelas cargas do veículo, além de servir de suporte aos trilhos, permitindo a sua fixação e mantendo a distância entre os mesmos (bitola) constante. Portanto, o tipo de dormente a ser implantado influencia e também é influenciado pelas características dos outros componentes da via permanente.

Para que o dormente possa cumprir suas finalidades, é preciso que ele tenha as seguintes características (BRINA, 1979):

a) Dimensões que forneçam uma superfície de apoio suficiente para que a taxa de trabalho no lastro não ultrapasse determinado limite;

b) Espessura que the dê a rigidez necessária, porém com alguma elasticidade;

c) Resistência suficiente aos esforços;

d) Durabilidade;

e) Consiga se opor eficazmente aos deslocamentos longitudinais e transversais da via;

f) Permita uma fixação firme do trilho, porém sem ser excessivamente rígida. 
Segundo a AREMA (Manual for Railway Engineering, 2009), o projeto do dormente deve levar em consideração diversos fatores, a fim de que se possa obter um produto que combine as características citadas acima:

a) Características do trilho, fixações, lastro, sub-lastro e sub-base;

b) A qualidade de cada componente, método de fabricação, instalação e manutenção;

c) A direção, magnitude e freqüência das cargas de tráfego;

d) Velocidade de tráfego;

e) Perfil e inclinação dos trilhos;

f) Tipo de fixação dos trilhos;

g) Características da plataforma e do traçado;

h) O efeito do clima e do meio ambiente;

i) Os aspectos econômicos da instalação e manutenção.

Os principais tipos de dormentes existentes no mercado são: de madeira, de concreto, de aço e, mais recentemente, de madeira plástica.

\subsubsection{Dormente de Madeira}

A madeira apresenta todas as qualidades exigidas para o dormente, porém, devido à escassez de fontes, às mais severas exigências ambientais e ao conseqüente encarecimento dos preços, este tipo de material teve seu uso bastante reduzido nos últimos anos, sendo substituído por outros tipos de dormentes.

O principal parâmetro a ser analisado em um dormente de madeira é a sua durabilidade, que está relacionada tanto à resistência mecânica, quanto à resistência ao apodrecimento.

A resistência mecânica do dormente está associada às características físicas (umidade, retrabilidade e peso específico) e características mecânicas da madeira, sendo que estes dois fatores dependem da micro-estrutura da madeira, 
principalmente de sua densidade. Na madeira a ser utilizada como dormente, algumas propriedades mecânicas são mais importantes que outras, como os limites de compressão e flexão do material. Também ganha importância avaliar a dureza da madeira, em especial do topo da peça, já que é o local onde será feita a fixação, responsável por transmitir os esforços horizontais do trilho (principalmente em curvas), além de o furo para a fixação tornar este local o ponto mais vulnerável do dormente.

A resistência ao apodrecimento depende, primeiramente, das características físicas da madeira. Como nas condições em que estas peças trabalham no Brasil (altas temperatura e umidade), o surgimento de fungos e insetos é bastante favorecido. Logo, passa a ser extremamente recomendável o tratamento químico dos dormentes com preservativos, a fim de prolongar sua vida útil (BRINA, 1979).

Os dormentes de madeira não tratados têm sua vida útil muito reduzida, em torno de 5 a 10 anos, enquanto que dormentes de madeira tratada podem ter vida útil de 20 anos, dependendo das condições de uso.

Os tipos de preservativos mais usados no tratamento químico dos dormentes têm a finalidade de tornar a madeira tóxica aos fungos e insetos, fazendo com que deixem de se alimentar deste material. Eles podem ser divididos em duas categorias: oleosos e hidrossolúveis.

Dentre os preservativos oleosos, os mais comumente utilizados são o creosoto (derivado do petróleo) e o pentaclorofenol, ambos com toxicidade de moderada a elevada.

Já os preservativos hidrossolúveis contêm em suas fórmulas mais de uma substância química e estão mais sujeitos à lixiviação, o que os tornam menos eficientes.

A escolha do tipo de preservativo a ser usado depende de muitas variáveis, sendo que a resistência da madeira é uma dos mais importantes. Caso o dormente tenha grande resistência mecânica e esteja protegido por uma boa fixação do trilho, o apodrecimento deverá ser o fator limitante de sua vida útil, por isso se justifica a 
adoção do preservativo mais eficiente e caro (no caso, o oleoso). No entanto, em vias destinadas ao transporte de mercadorias, com maior densidade de tráfego e cargas elevadas, geralmente a substituição do dormente se dá por desgaste mecânico, portanto pode ser justificável a utilização de um preservativo menos eficiente, mas mais econômico.

Em resumo, é possível concluir que a escolha do dormente de madeira se apóia em 4 fatores principais:

a) resistência à destruição mecânica;

b) resistência ao apodrecimento;

c) facilidade de obtenção da madeira;

d) custos.

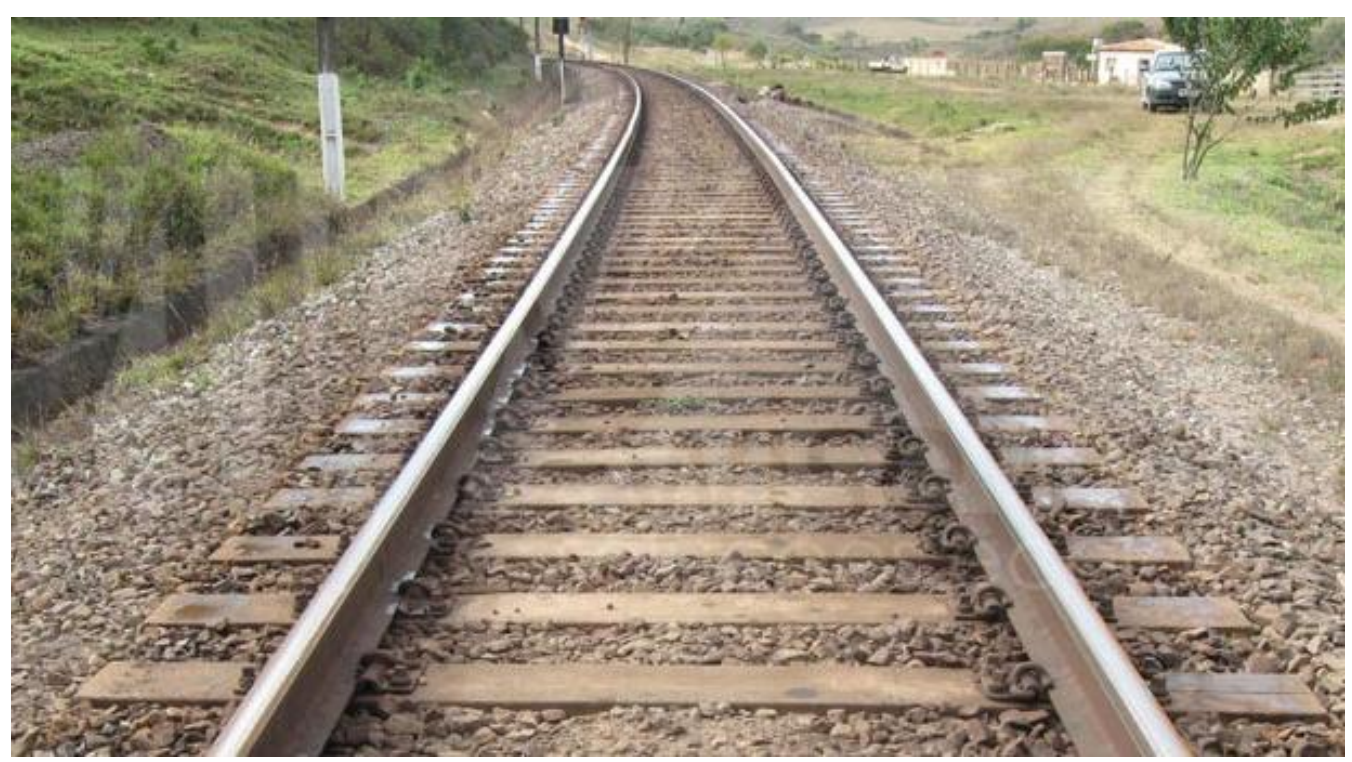

Figura 8: Dormente de Madeira, em via operada pela MRS Logística S.A.

FONTE: MRS Logística S.A., 2010

A Tabela 4, a seguir, indica as dimensões padrão que o dormente de madeira deve apresentar, além das tolerâncias dimensionais que podem ser admitidas em cada peça. 
Tabela 4: Dimensões e Tolerâncias do Dormente de Madeira

\begin{tabular}{cccc}
\hline Bitola & Comprimento $(\mathbf{m})$ & Largura $(\mathbf{m})$ & Altura $(\mathbf{m})$ \\
\hline $1,00 \mathrm{~m}$ & $2,00+/-0,05$ & $0,22+/-0,02$ & $0,16+/-0,01$ \\
$1,435 \mathrm{~m}$ & $2,65+/-0,05$ & $0,24+/-0,02$ & $0,17+/-0,01$ \\
$1,60 \mathrm{~m}$ & $2,80+/-0,05$ & $0,24+/-0,02$ & $0,17+/-0,01$ \\
\hline
\end{tabular}

FONTE: ABNT - Associação Brasileira de Normas Técnicas, 2005

Os tipos de madeira utilizados como dormente são, usualmente, divididos em dois grupos (ou classes), que classificam as espécies de acordo com a qualidade do material, sendo as madeiras consideradas nobres pertencentes ao primeiro grupo (CBTU - Especificação de Material - Dormente de Madeira, 2002). Obviamente, o uso das madeiras nobres pertencentes ao que é denominado Grupo 1, tais como Ipê, Jatobá e Angico, já não encontra mais aplicação comercial. Assim, a alternativa encontrada para o uso da madeira nativa em dormentes tem sido a adoção da madeira de eucaliptos (pertencente ao Grupo 2), fruto de áreas de reflorestamento. Embora seja considerada menos nobre (comumente denominada como "mole"), esta madeira apresenta características físicas muitas vezes superiores às encontradas em diversas madeiras "de lei".

A Tabela 5, a seguir, fornece os índices mínimos para algumas das características principais que a madeira a ser utilizada como dormente deve apresentar. O eucalipto, apesar de ser pertencente ao Grupo 2, possui índice de dureza em torno de $870 \mathrm{~kg} / \mathrm{cm}^{2}$ e outras características, como a resistência ao cisalhamento, iguais ou superiores às encontradas em madeiras nobres (BRINA, 1979).

Tabela 5: Propriedades Físicas das Madeiras, de acordo com o Grupo

\begin{tabular}{lccc}
\hline \multirow{2}{*}{ Características } & \multirow{2}{*}{ Unidade } & \multicolumn{2}{c}{ Índices Mínimos } \\
\cline { 3 - 4 } & & Grupo 1 & Grupo 2 \\
\hline Peso Específico & $\mathrm{g} / \mathrm{cm}^{3}$ & 0,75 & 0,60 \\
Dureza & $\mathrm{kg} / \mathrm{cm}^{2}$ & 500,00 & 400,00 \\
Cisalhamento & $\mathrm{kg} / \mathrm{cm}^{2}$ & 100,00 & 80,00 \\
Tração Normal & $\mathrm{kg} / \mathrm{cm}^{2}$ & 75,00 & 50,00 \\
Grau de Coesão & - & 3,00 & 2,00 \\
\hline
\end{tabular}

FONTE: CBTU - Especificação de Material - Dormente de Madeira, 2002 
No entanto, a durabilidade do eucalipto, em alguns casos, pode ser até $50 \%$ inferior à da madeira "de lei", em virtude de sua maior sensibilidade ao ataque de microorganismos, o que reduz sensivelmente a vida útil do dormente. Dados obtidos junto à área de manutenção da concessionária MRS Logística S.A. mostram que, em alguns trechos de sua malha férrea onde as chuvas são mais constantes e a geometria do traçado é mais desfavorável, a durabilidade dos dormentes de madeira (no caso, eucalipto) é de cerca de 5 anos, sendo que já foram registrados casos em que a substituição destas peças ocorreu depois de apenas 2 anos.

Esta vida útil reduzida tem levado à pesquisa e testes para a substituição deste tipo de dormente por outros de materiais alternativos, como o plástico reciclado.

\subsubsection{Dormente de Madeira Plástica}

A crescente preocupação mundial em relação à preservação de florestas e reciclagem de materiais fez com que, nos últimos anos, a busca por tecnologias alternativas ao uso da madeira natural em dormentes ganhasse grande importância, resultando no desenvolvimento de peças que utilizam materiais descartados, como plásticos e borracha de pneu (FARIA, 2006).

A produção em larga escala dos dormentes de madeira plástica (ou plástico, apenas) teve início no final do século XX, principalmente nos Estados Unidos. Este componente apresenta como diferencial em relação à madeira o fato de ter prevista uma longa vida útil, em torno de 40 a 50 anos para vias que operam com transporte de cargas pesadas, como minério de ferro. Foi desenvolvido visando à geração de um produto que supera as características do melhor dormente de madeira natural existente, que é aquele feito a partir do carvalho (WISEWOOD, 2011).

Algumas das considerações gerais mais pertinentes feitas pela AREMA (Manual for Railway Engineering, 2009) acerca deste tipo de dormente estão relacionadas a seguir:

a) O uso dos dormentes de madeira plástica, embora possa apresentar diferentes condicionantes para o seu projeto e instalação, pode ser usado 
sem maiores prejuízos em novas construções ou na manutenção de vias férreas cuja grade ferroviária possui dormente de madeira natural;

b) O projeto deste tipo de dormente deve considerar o mesmo espaçamento e a mesma estrutura para a camada de lastro que os adotados para os projetos com dormentes de madeira natural;

c) A fim de aumentar a estabilidade lateral e longitudinal da via, o dormente de madeira plástica pode ser produzido com um formato especial de sua superfície (por exemplo: com extremidades que proporcionem maior área de contato ou penetração no lastro), de maneira que seja criada uma interligação mecânica entre o lastro e o dormente;

d) A análise sobre as exigências para a aplicação deste dormente deve levar em conta não apenas as características deste produto, mas também dos demais componentes da superestrutura ferroviária (trilhos, fixações, lastro e sub-lastro), suas relações de interdependência e as condições sobre as quais eles podem ser utilizados.

Ainda segundo a AREMA (Manual for Railway Engineering, 2009), as propriedades físicas e mecânicas do dormente de madeira plástica devem atender aos seguintes requisitos:

a) O dormente deve ter flexibilidade suficiente para absorver as vibrações produzidas pela passagem do trem, além de suportar as cargas aplicadas mantendo a via nivelada e estável em todos os sentidos;

b) O dormente deve permitir a instalação dos trilhos, fixações e placas de apoio sem que sejam necessários procedimentos especiais ou adaptações dos produtos por parte dos fabricantes;

c) O dormente não deve apresentar alterações que possam levar à sua ruptura devido às variações térmicas ou apresentar deformações permanentes que possam levar à substituição da peça;

d) A degradação superficial da peça devido à exposição à radiação ultravioleta (UV) não deve exceder a taxa de 0,076 mm por ano. 
Além de todas as características já citadas anteriormente, que são muito similares àquelas encontradas nos dormentes de madeira natural, o dormente de madeira plástica apresenta a vantagem de ser impermeável à água e imune aos efeitos biológicos, o que contribui fortemente para que sua vida útil seja elevada e para que seja recomendada a sua instalação em locais onde há muita umidade e variações climáticas.

Conforme ilustra a Tabela 6, as dimensões deste tipo de dormente são as mesmas do dormente de madeira natural.

Tabela 6: Dimensões dos Dormentes de Madeira Plástica

\begin{tabular}{ccccc}
\hline Bitola $(\mathbf{m})$ & $\begin{array}{c}\text { Comprimento } \\
(\mathbf{m m})\end{array}$ & $\begin{array}{c}\text { Largura } \\
(\mathbf{m m})\end{array}$ & $\begin{array}{c}\text { Altura } \\
(\mathbf{m m})\end{array}$ & $\begin{array}{c}\text { Peso por Peça } \\
(\mathbf{k g})\end{array}$ \\
\hline 1,600 & 2800 & 240 & 170 & 115,0 \\
1,435 & 2300 & 240 & 170 & 98,0 \\
1,000 & 2000 & 240 & 170 & 75,0 \\
\hline
\end{tabular}

FONTE: Wisewood, 2011

É importante observar que o seu peso por peça (115 kg para a bitola de 1,600 m) é bastante inferior ao peso do dormente de concreto protendido monobloco, por exemplo (em torno de 350 a $400 \mathrm{~kg}$ para a mesma bitola). Este é um fator que indica, ao menos teoricamente, que a via com dormente de madeira plástica deve apresentar menor estabilidade longitudinal e lateral em curvas, quando comparada à mesma via assentada sobre dormente de concreto monobloco.

No Brasil, a oferta de fabricantes e de produção deste tipo de dormente já é insuficiente frente à demanda existente por parte das concessionárias operadoras de trens de carga.

A Wisewood, empresa situada em Itatiba - SP, é atualmente aquela que detém a maior capacidade de produção nacional. Seus dormentes são produzidos a partir de resíduos plásticos de polietileno (PEAD) e resíduos minerais, como fibra de vidro. 


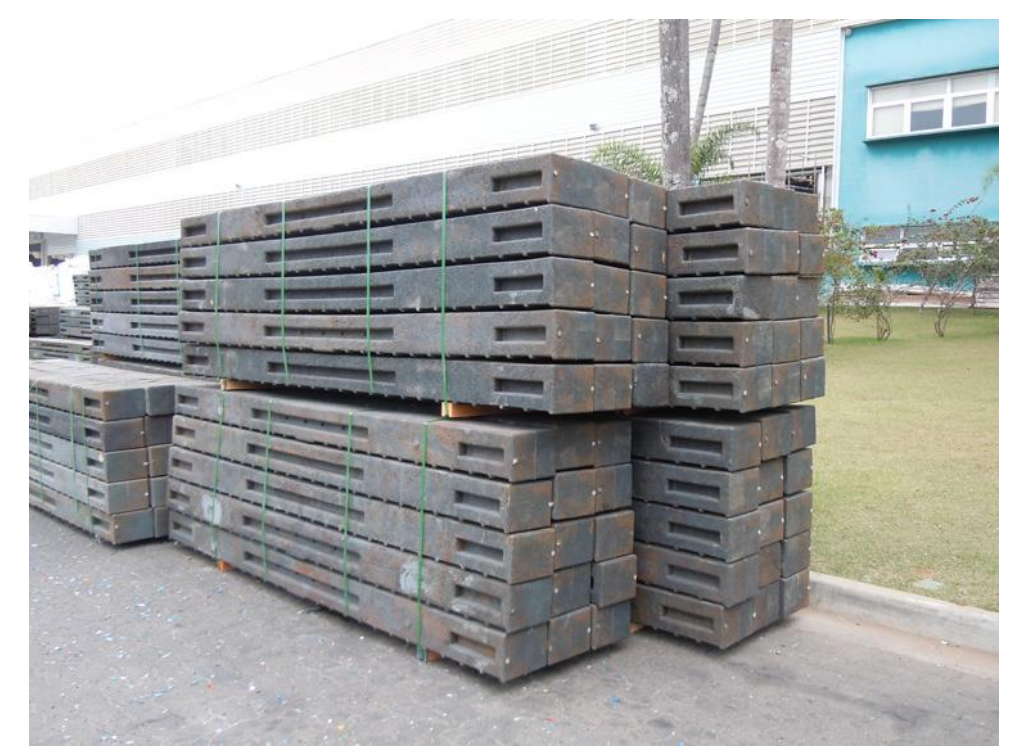

Figura 9: Dormente de Madeira Plástica

FONTE: Wisewood, 2011

As operadoras de transporte de carga nacionais já realizam testes em campo com estes dormentes, a fim de monitorar seu desempenho e vida útil.

A concessionária MRS Logística S.A., desde 2008, tem instalados em suas vias 1.800 dormentes de madeira plástica, tanto intercalados com os de madeira natural (ver Figura 10), como em seqüência, em trechos em reta e em curvas. Estas vias, desde então, tem sido monitoradas e analisadas quanto ao seu módulo de elasticidade, para a obtenção de estimativas da vida útil destas peças. Os últimos resultados divulgados pela empresa indicam a expectativa de vida útil dos dormentes entre 9 e 13 anos, dependendo do trecho analisado e do fornecedor. Vale ressaltar que estes valores são atualizados anualmente, conforme a evolução da análise dos dados mais atuais provenientes do monitoramento. Ou seja, a estimativa da vida útil tende a aumentar à medida que mais informações a respeito do desempenho da via serão acumuladas. Os técnicos da empresa envolvidos no teste acreditam que, fazendo-se uma projeção a partir dos dados atuais, a vida útil do dormente de madeira plástica ficará entre 25 e 30 anos, o que já é um resultado bastante superior ao que a empresa verifica com os dormentes de madeira natural (SOARES, 2011). Porém, este valor estimado ainda é menor que aquele declarado pelos fabricantes do dormente plástico, que é em torno de 40 a 50 anos. 


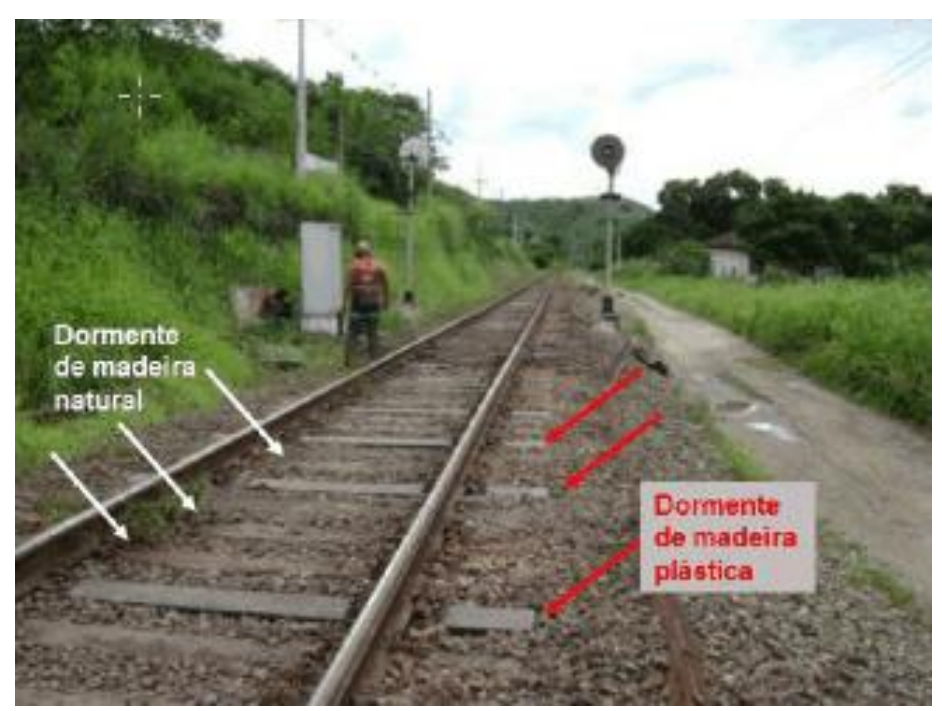

Figura 10: Dormente de Madeira Plástica em Via da MRS Logística S.A.

FONTE: Wisewood, 2011

Apesar de os testes práticos realizados com este tipo de dormente serem recentes, alguns mecanismos de falha já puderam ser constatados, devido à sua recorrência. Um dos mecanismos está relacionado ao surgimento de trincas superficiais na região onde é feita a furação do dormente para instalação da placa de apoio do trilho. Foi verificado que este problema tem origem no processo de instalação da peça, onde eram usados os mesmos equipamentos e técnicas aplicados ao dormente de madeira natural, que, no entanto, mostraram-se inadequados neste caso (SOARES, 2011).

Fica claro que a ocorrência de falhas como a relatada acima é um fator difícil de ser previsto, porém é essencial que o profissional responsável pelo projeto e seleção dos componentes da grade ferroviária tenha conhecimento sobre estes dados, pois informações como essa, embora não estejam diretamente relacionadas ao projeto, podem ter grande influência na decisão final sobre qual tipo de componente será implantado na via. Some-se a isso o fato de ainda não existir, até a presente data, uma norma técnica nacional que estabeleça os requisitos de desempenho e características que os dormentes de madeira plástica devem apresentar. Portanto, a ocorrência de falha como a descrita acima pode e deve ser divulgada, visando até mesmo que a futura norma técnica brasileira a ser desenvolvida especifique 
procedimentos-padrão para mitigar ou corrigir os problemas que já são conhecidos neste tipo de peça.

\subsubsection{Dormente de Concreto}

Os dormentes de concreto estão associados ao conceito de "via permanente elástica", desenvolvido inicialmente pela escola ferroviária francesa (ALIAS, 1987).

Apesar de os primeiros dormentes de concreto terem sido produzidos no final do século 19, até o início da década de 1940 as ferrovias utilizavam quase que exclusivamente os dormentes de madeira. A escassez da madeira de boa qualidade em muitos países, principalmente após a $2^{\underline{a}}$ Guerra Mundial, levou a uma grande intensificação no emprego dos dormentes de concreto.

Atualmente, com mais de 60 anos de experiência e desenvolvimento tecnológico, os dormentes de concreto já se tornaram um produto consagrado em âmbito mundial, sendo que seu uso vem se tornando cada vez mais freqüente, principalmente devido a algumas de suas vantagens técnicas frente aos demais tipos de dormentes.

Algumas das vantagens dos dormentes de concreto que justificam o crescimento do interesse mundial pelo seu uso estão citadas abaixo:

a) Alta resistência lateral e vertical, devido à maior massa do concreto;

b) Via com geometria mais estável, resultando em rolamento mais suave, seguro e maior conforto para os passageiros;

c) Alta vida útil do dormente, estimada em 50 anos ou mais;

d) Menores índices de manutenção e menor custo total pelo ciclo de vida útil;

e) Menor taxa de dormentação em comparação com outros tipos de dormentes, exigindo um menor número de unidades por quilômetro de via;

f) Elevada homogeneidade e consistência na qualidade da produção; 
g) Elevado desempenho sob condições de tráfego muito severas, incluindo as vias de carga pesada e de alta velocidade;

h) Versatilidade no emprego dos mais diversos sistemas de fixação dos trilhos;

i) Custo bastante competitivo em comparação com os outros tipos de dormentes, sobretudo se forem considerados todos os custos envolvidos na manutenção da via permanente a médio e longo prazos.

\subsubsection{Dormente de Concreto Protendido Monobloco}

Os dormentes de concreto monobloco consistem basicamente de uma viga monolítica de concreto protendido, conforme mostrado na Figura 11, abaixo.

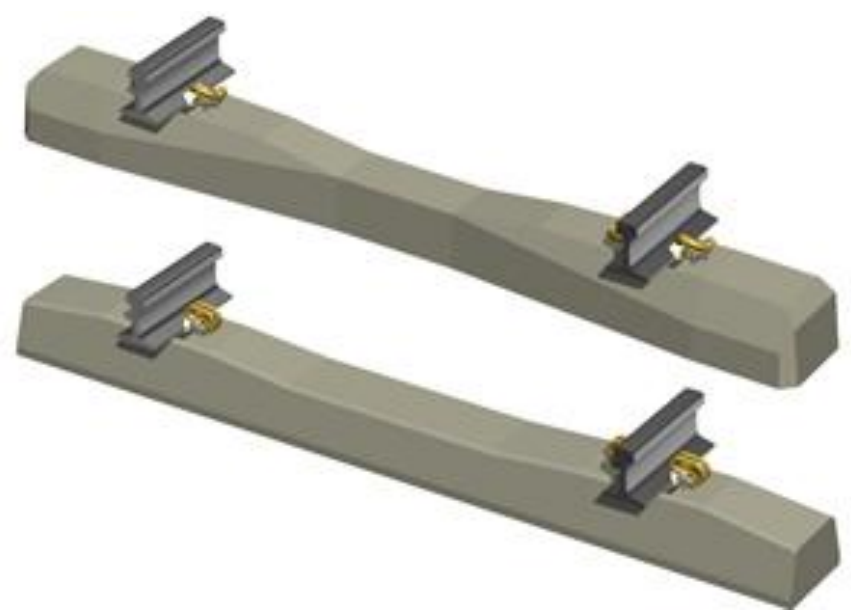

Figura 11: Dormente Protendido Monobloco FONTE: Catálogo Dorbrás

Os dormentes de concreto monobloco são, em geral, peças de concreto bastante robustas, capazes de atender aos requisitos de desempenho estabelecidos pelas normas nacionais e internacionais do setor ferroviário.

Além das vantagens tipicamente proporcionadas pelos dormentes de concreto, já mencionadas anteriormente, os dormentes monobloco de concreto protendido apresentam as seguintes vantagens adicionais: 
a) Em virtude de sua forma monolítica podem ser instalados em vias de bitola mista, com três ou quatro fiadas de trilhos;

b) Sua elevada massa, que varia entre $350 \mathrm{~kg}$ e $400 \mathrm{~kg}$ por peça, lhes confere uma excelente estabilidade, o que é especialmente importante em curvas;

c) Podem ser utilizados como suportes dos trilhos nos aparelhos de mudança de via (AMVs), melhorando o desempenho desses equipamentos;

d) Para as aplicações envolvendo cargas por eixo muito elevadas e produção em larga escala, tendem a ser mais econômicos que os dormentes bi-bloco, em virtude do seu menor consumo de aço por dormente.

Para a fabricação dos dormentes monobloco, são utilizados fios ou cordoalhas de protensão da alta aderência e baixa relaxação, além de concreto plástico de alta resistência (fck > $45 \mathrm{MPa}$ ) endurecido por processo de cura térmica acelerada. Por exigir o emprego de um grande número de fôrmas metálicas, o processo de fabricação dos dormentes monobloco é especialmente recomendado para produções em larga escala, que não exijam freqüentes alterações no modelo de dormente produzido.

Deve-se, porém, citar também algumas desvantagens que já puderam ser constatadas na utilização deste tipo de dormente (BASTOS, 1999), como:

a) A reutilização do dormente após descarrilamento é questionável;

b) Seu tempo de vida útil é um valor estimativo, pois ainda não foi completamente avaliado em condições de serviço;

c) Sua fabricação exige elevado controle de qualidade, a fim de garantir a homogeneidade das peças.

\subsubsection{Dormente de Concreto Bi-Bloco}

O dormente bi-bloco (ou dormente misto) consiste basicamente de dois blocos de concreto armado interligados por um perfil metálico. Apesar da configuração simples, são peças muito complexas, projetadas para ter longa vida útil, resistindo 
às intempéries e aos elevados esforços, vibrações e impactos dinâmicos aos quais são submetidas na via permanente.

Sua concepção parte do conhecimento de que, como as cargas de roda aplicadas aos trilhos são distribuídas pelos dormentes sobre uma porção limitada do lastro, ou seja, apenas sobre a porção do lastro situada na região abaixo dos trilhos, não há a necessidade de se manter uma estrutura monolítica, o que torna dispensável a massa de concreto da parte central do dormente. Este tipo de solução permite dobrar a área de apoio lateral contra o lastro, além de eliminar o risco de fratura no centro do dormente por flexão negativa (o dormente é quase imune aos esforços de flexão) e a perda de estabilidade resultante do apoio da parte central do dormente sobre o lastro.

Os dormentes de concreto bi-bloco são fabricados com armaduras de barras de aço nervuradas conformadas em laço, além de concreto seco (slump zero) de alta resistência, com fck geralmente acima de $40 \mathrm{MPa}$ e peso total de aproximadamente $180 \mathrm{~kg}$. As vigas de interligação são produzidas em aços estruturais de elevada resistência à corrosão, que garantem a manutenção da bitola, sem comprometer a elasticidade da via.

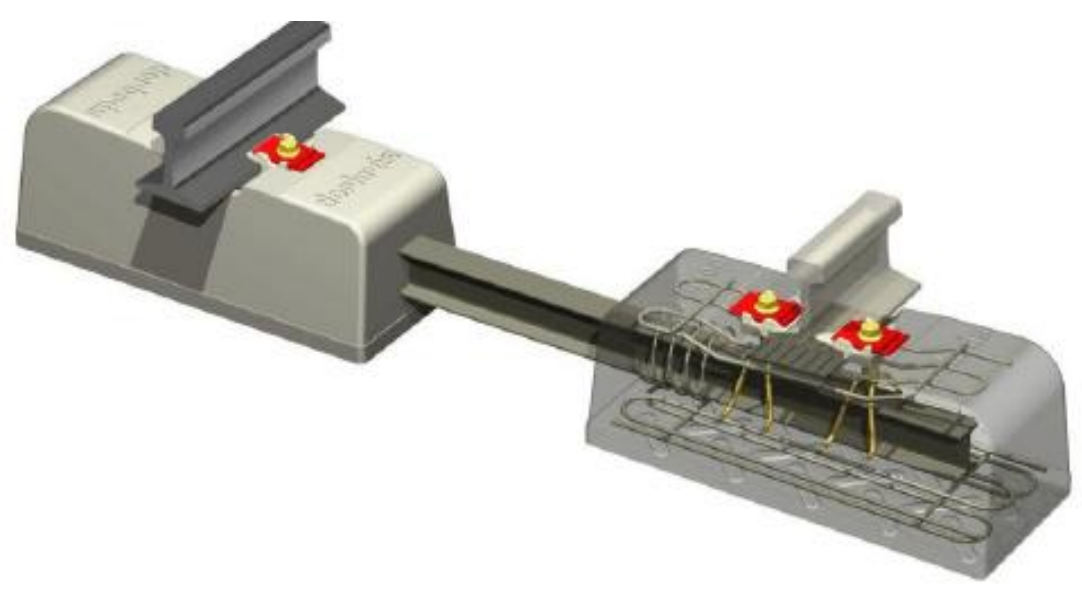

Figura 12: Dormente Bi-Bloco com Fixação Elástica Aparafusada FONTE: Catálogo Dorbrás 


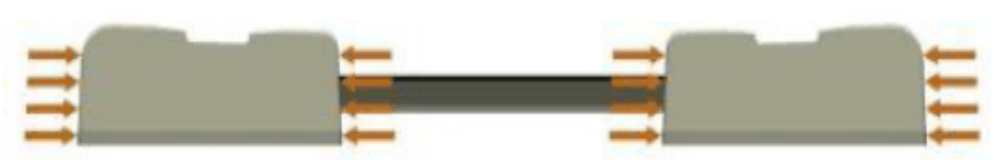

Figura 13: Croqui llustrativo das 4 Faces de Apoio Lateral do Dormente Bi-bloco FONTE: Catálogo Dorbrás

Quanto aos diferentes tipos de fixações, os dormentes de concreto bi-bloco se adaptam tanto às fixações do tipo aparafusadas (AP, RN, DB2, S.75L, etc.) como também às fixações do tipo grampo (Deenik, Pandrol e-Clip, Pandrol FastClip, etc.), o que proporciona uma grande liberdade de escolha às ferrovias, visto que podem ser utilizados com qualquer tipo de fixação duplamente elástica, ou seja, que utilize palmilha elástica.

Os principais diferenciais deste tipo de dormente são os seguintes:

a) Em razão das quatro áreas de apoio lateral contra o lastro, possui a maior resistência lateral dentre todos os tipos de dormentes disponíveis no mercado, diminuindo o risco de desvio na geometria da via e de flambagem lateral dos trilhos, principalmente em aplicações de carga elevada e curva de raio pequeno (raio $<400 \mathrm{~m}$ );

b) São mais leves em relação aos dormentes monobloco (para uma mesma carga por eixo), o que facilita as operações de transporte, manuseio, assentamento, manutenção e substituição;

c) A via com dormente bi-bloco normalmente apresenta maior flexibilidade que a com dormente monobloco, o que resulta em menor desgaste dos trilhos e rodas dos trens, além de propiciar maior conforto e qualidade do rolamento;

d) A presença da viga de interligação em aço estrutural da alta resistência permite uma maior tolerância a problemas de manutenção deficiente do lastro e recalques na plataforma da via, visto que este tipo de dormente é menos sensível ao momento fletor negativo que age em seu centro. 
Apesar de os dormentes de concreto bi-bloco apresentarem diversos diferenciais e algumas vantagens em relação aos demais tipos de dormentes, existem também alguns problemas relacionados à sua aplicação, citados a seguir:

a) Dificuldade de fabricação das peças com homogeneidade, em virtude da ligação da viga de aço com o bloco de concreto. Em muitos casos, rupturas ou trincas ocorrem nesta região de interligação, por constituir um ponto frágil no componente;

b) Por ser formado por dois blocos de concreto armado independentes, existe certa dificuldade em executar corretamente o nivelamento do dormente durante a sua instalação;

c) Por ser mais leve que o dormente de concreto protendido monobloco, a perda em estabilidade pode ser considerável, principalmente se a socaria do lastro não for feita de maneira cuidadosa e garantindo que todas as faces dos dois blocos de concreto armado fiquem devidamente confinadas.

\subsubsection{Dormente de Aço}

O dormente de aço consiste, basicamente, de uma chapa laminada, em forma de $U$ invertido, curvada em suas extremidades. Esta curvatura em suas extremidades tem a finalidade de formar "apoios" que penetram no lastro e se opõem à tendência de deslocamento transversal da via (BRINA, 1979).

O emprego do aço torna este tipo de dormente muito mais leve, em comparação aos demais existentes, com peso em torno de $70 \mathrm{~kg}$, o que contribui para que seu assentamento seja facilitado. No entanto, esta leveza condena seu uso em linhas que operam com cargas elevadas, onde é importante que o dormente apresente maior inércia, para proporcionar estabilidade à via.

Apresenta como vantagem o fato de ter elevada vida útil, estimada em acima de 60 anos, além de exigir uma menor taxa de dormentação, em comparação ao dormente de madeira natural. 


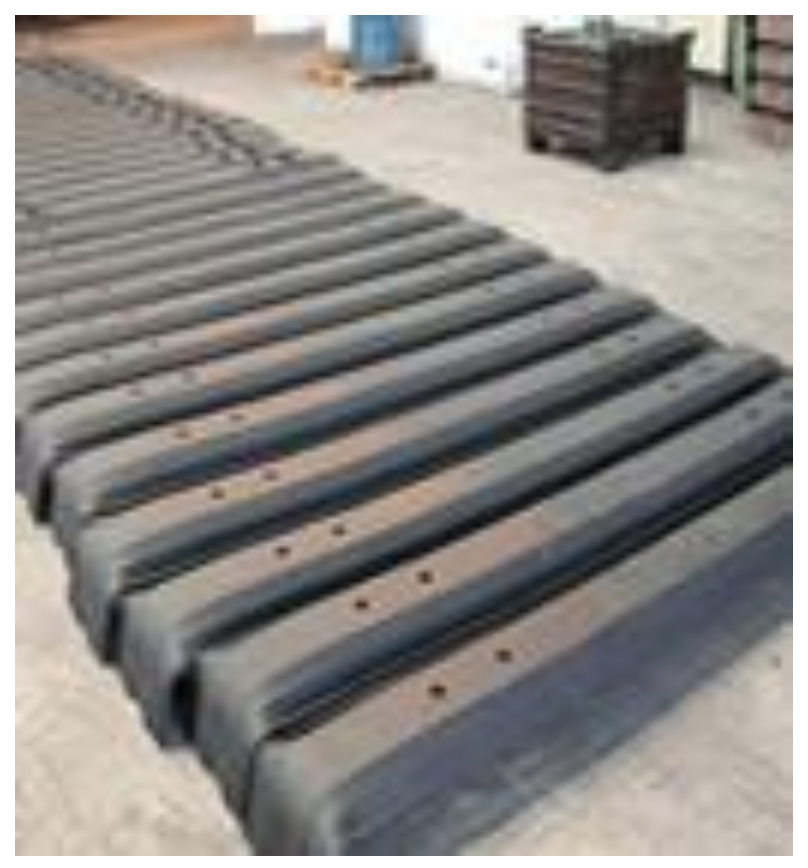

Figura 14: Dormente de Aço UIC 865-2

FONTE: Site Hidremec

Porém, surgem também algumas desvantagens provenientes do uso do aço como material, tais como:

a) o aço é bom condutor de eletricidade, o que dificulta o isolamento dos trilhos para a instalação dos circuitos de sinalização;

b) o uso do aço traz grande rigidez ao dormente, o que não é desejável, já que sempre se busca uma configuração para os componentes da superestrutura que dê elasticidade à via;

c) o formato do dormente torna a socaria do lastro mais difícil, especialmente no caso do processo totalmente mecanizado;

d) no caso brasileiro, o custo de fabricação do dormente de aço pode tornar seu emprego inviável, devido à escassa oferta siderúrgica no país. Vale lembrar que grande parte dos trilhos utilizados em nossas ferrovias é importada, o que mostra a deficiência de nossa indústria nesta área, onde sequer a demanda por trilhos consegue ser suprida. 


\subsubsection{Análise Comparativa e Resumo das Características dos Dormentes}

Após a apresentação e a descrição das principais características e requisitos de desempenho dos dormentes presentes no mercado nacional, torna-se necessária a análise comparativa do desempenho destas peças.

QUEIROZ (2007) realizou um estudo experimental comparativo das resistências da grade ferroviária, em escala natural, utilizando dormentes de madeira, de concreto protendido monobloco, de concreto bi-bloco e de aço. O modelo executado, composto por via em bitola de 1,600 m, trilhos TR-68, fixação elástica Pandrol e camada de lastro com espessura de $35 \mathrm{~cm}$, foi avaliado quanto ao seu comportamento frente à ação de esforços longitudinais e transversais.

Neste estudo, a resistência longitudinal da via equipada com cada tipo de dormente foi determinada a partir da aplicação de carga até ser verificado um deslocamento de $15 \mathrm{~mm}$ no dormente. A Tabela 7, abaixo, apresenta os valores obtidos. Percebese que o dormente de concreto monobloco apresentou o maior valor para a resistência longitudinal, fato que comprova a influência significativa que o seu maior peso tem neste aspecto.

Tabela 7: Comparação entre os Esforços e Deslocamentos Longitudinais para os Dormentes Estudados

\begin{tabular}{cc}
\hline Tipo de Dormente & $\begin{array}{c}\text { Resistência por Dormente para } \\
\text { Deslocamento de 15 } \mathbf{~ m m ~ ( k N )}\end{array}$ \\
\hline Madeira & 7,57 \\
Concreto Monobloco & 9,86 \\
Concreto Bi-bloco & 8,86 \\
Aço & 6,43 \\
\hline
\end{tabular}

FONTE: QUEIROZ, 2007

Foi também determinada no estudo a estabilidade lateral da via para cada tipo de dormente de forma análoga à anterior, a partir da aplicação de carga na via até ser verificado um deslocamento transversal de $25 \mathrm{~mm}$. Os resultados da resistência lateral por dormente (ver Tabela 8), mostram que o dormente de concreto bi-bloco possui a maior estabilidade, comprovando que o fato desta peça contar com 4 faces 
de contato lateral realmente conduz a melhores resultados. Deve-se destacar também o resultado obtido pelo dormente de aço, que atesta a melhora produzida na estabilidade lateral em virtude desta peça contar com abas nas extremidades que penetram no lastro e o embutimento de lastro em sua parte interna.

Tabela 8: Comparação entre os Esforços e Deslocamentos Transversais para os Dormentes Estudados

\begin{tabular}{cc}
\hline Tipo de Dormente & $\begin{array}{c}\text { Resistência por Dormente para } \\
\text { Deslocamento de } \mathbf{2 5} \mathbf{~ m m} \mathbf{( k N )}\end{array}$ \\
\hline Madeira & 4,86 \\
Concreto Monobloco & 6,14 \\
Concreto Bi-bloco & 9,14 \\
Aço & 8,14 \\
\hline
\end{tabular}

FONTE: QUEIROZ, 2007

As conclusões do estudo experimental descrito acima mostraram-se coerentes em relação às características de desempenho dos dormentes pesquisadas na literatura e junto aos fabricantes e empresas concessionárias de transporte de carga.

Embora o estudo não tenha abordado os dormentes de plástico, é possível prever que seus valores de resistência longitudinal e transversal sejam ao menos iguais ou até superiores aos verificados na madeira, uma vez que este dormente, conforme recebe a ação do carregamento, passa a sofrer "embutimento" do lastro em sua superfície inferior, o que certamente contribui com o incremento de sua estabilidade (SOARES, 2011).

Feitas estas considerações, torna-se possível reunir os principais dados técnicos pesquisados em uma única tabela comparativa (a seguir), fornecendo um resumo dos itens analisados. 
Tabela 9: Resumo das Características dos Dormentes

\begin{tabular}{|c|c|c|c|c|c|}
\hline \multirow[b]{2}{*}{ Características } & \multicolumn{5}{|c|}{ Tipo de Dormente } \\
\hline & $\begin{array}{c}\text { Madeira } \\
\text { (Eucalipto) }\end{array}$ & Plástico & $\begin{array}{c}\text { Concreto } \\
\text { Monobloco }\end{array}$ & $\begin{array}{r}\text { Concreto } \mathrm{Bi}- \\
\text { bloco }\end{array}$ & Aço \\
\hline Peso (kg) & $120-140$ & $120-130$ & $350-400$ & $180-200$ & $70-80$ \\
\hline Vida Útil (anos) & $5-20$ & $\begin{array}{c}25-30 \\
\text { (estimado) }\end{array}$ & $\begin{array}{c}\text { Acima de } 50 \\
\text { (estimado) }\end{array}$ & $\begin{array}{c}\text { Acima de } 50 \\
\text { (estimado) }\end{array}$ & $\begin{array}{c}\text { Acima de } 50 \\
\text { (estimado) }\end{array}$ \\
\hline $\begin{array}{c}\text { Resistência ao } \\
\text { ataque de } \\
\text { Microorganismo }\end{array}$ & $\begin{array}{l}\text { Sim (se } \\
\text { tratado) }\end{array}$ & Sim & Sim & Sim & Sim \\
\hline Ruído c/ Tráfego & Não & Não & Não & Não & Sim \\
\hline $\begin{array}{l}\text { Promove } \\
\text { Isolamento } \\
\text { Elétrico? }\end{array}$ & Sim & Sim & Sim & Sim & Não \\
\hline $\begin{array}{l}\text { Resistência para } \\
\text { Deslocamento } \\
\text { Longitudinal de } \\
15 \mathrm{~mm}(\mathrm{kN})\end{array}$ & 7,57 & $\begin{array}{c}\text { lgual ou } \\
\text { superior à } \\
\text { madeira } \\
\text { (estimativa } \\
\text { baseada nos }\end{array}$ & 9,86 & 8,86 & 6,43 \\
\hline $\begin{array}{c}\text { Resistência para } \\
\text { Deslocamento } \\
\text { Lateral em } \\
\text { Curvas de } 25 \\
\text { mm (kN) }\end{array}$ & 4,86 & $\begin{array}{l}\text { testes de } \\
\text { campo ainda } \\
\text { em curso - } \\
\text { MRS Logística } \\
\text { S.A.) }\end{array}$ & 6,14 & 9,14 & 8,14 \\
\hline
\end{tabular}


Continuação da Tabela 9:

\begin{tabular}{|c|c|c|c|c|c|}
\hline \multirow[b]{2}{*}{ Características } & \multicolumn{5}{|c|}{ Tipo de Dormente } \\
\hline & $\begin{array}{c}\text { Madeira } \\
\text { (Eucalipto) }\end{array}$ & Plástico & $\begin{array}{c}\text { Concreto } \\
\text { Monobloco }\end{array}$ & $\begin{array}{r}\text { Concreto } \mathrm{Bi}- \\
\text { bloco }\end{array}$ & Aço \\
\hline $\begin{array}{c}\text { Recomendações } \\
\text { de Uso } \\
\text { (baseadas no } \\
\text { desempenho) }\end{array}$ & $\begin{array}{c}\text { Recomendado } \\
\text { o uso em vias } \\
\text { com alta carga } \\
\text { por eixo de } \\
\text { vagão e que } \\
\text { atravessam } \\
\text { áreas urbanas. }\end{array}$ & $\begin{array}{l}\text { Ainda em fase } \\
\text { de testes, } \\
\text { porém com } \\
\text { dados de } \\
\text { desempenho } \\
\text { similares ou } \\
\text { superiores ao } \\
\text { dormente de } \\
\text { madeira, mas } \\
\text { com } \\
\text { expectativa de } \\
\text { vida útil } \\
\text { bastante } \\
\text { superior. }\end{array}$ & $\begin{array}{c}\text { Elevada } \\
\text { massa } \\
\text { proporciona } \\
\text { alta } \\
\text { estabilidade } \\
\text { da via e, em } \\
\text { consequência, } \\
\text { menor } \\
\text { manutenção. } \\
\text { Indicado para } \\
\text { vias com } \\
\text { maiores } \\
\text { velocidades } \\
\text { operacionais } \\
\text { e cargas por } \\
\text { eixo acima de } \\
35 \text { tf. }\end{array}$ & $\begin{array}{c}\text { Uso indicado } \\
\text { em vias muito } \\
\text { sinuosas, com } \\
\text { raios de curva } \\
\text { inferiores a } \\
500 m \text { e com } \\
\text { velocidades } \\
\text { operacionais } \\
\text { mais } \\
\text { elevadas. }\end{array}$ & $\begin{array}{c}\text { Seu baixo } \\
\text { peso não } \\
\text { torna sua } \\
\text { aplicação } \\
\text { recomendável } \\
\text { em vias que } \\
\text { transportem } \\
\text { altas cargas } \\
\text { por eixo. A } \\
\text { dificuldade } \\
\text { com o } \\
\text { isolamento } \\
\text { elétrico } \\
\text { também é } \\
\text { outro fator a } \\
\text { ser } \\
\text { considerado. }\end{array}$ \\
\hline
\end{tabular}

\begin{tabular}{|c|c|c|c|c|c|}
\hline $\begin{array}{l}\text { Situação Atual } \\
\text { do Mercado } \\
\text { Nacional }\end{array}$ & $\begin{array}{c}\text { Reduzida } \\
\text { oferta de } \\
\text { material; tende } \\
\text { a ser } \\
\text { gradativament } \\
\text { e substituído } \\
\text { pelo dormente } \\
\text { de plástico. }\end{array}$ & $\begin{array}{c}\text { Fornecedores } \\
\text { insuficientes } \\
\text { para } \\
\text { atendimento } \\
\text { da demanda } \\
\text { crescente; } \\
\text { necessita } \\
\text { ainda que } \\
\text { normatização } \\
\text { seja } \\
\text { estabelecida } \\
\text { no país. }\end{array}$ & $\begin{array}{c}\text { Material } \\
\text { largamente } \\
\text { empregado; o } \\
\text { aumento da } \\
\text { alta } \\
\text { produtividade } \\
\text { em larga } \\
\text { escala tende a } \\
\text { reduzir seu } \\
\text { custo inicial. } \\
\text { Permite } \\
\text { instalação } \\
\text { totalmente } \\
\text { mecanizada. }\end{array}$ & $\begin{array}{c}\text { No Brasil, } \\
\text { ainda não tem } \\
\text { grande } \\
\text { aplicação em } \\
\text { vias de } \\
\text { transporte de } \\
\text { carga (é } \\
\text { preterido em } \\
\text { relação ao } \\
\text { monobloco), } \\
\text { porém sua } \\
\text { instalação em } \\
\text { vias com } \\
\text { curvas de raio } \\
\text { pequeno deve } \\
\text { ser melhor } \\
\text { considerado. }\end{array}$ & $\begin{array}{l}\text { Alto custo de } \\
\text { produção } \\
\text { inibe a sua } \\
\text { aplicação em } \\
\text { maior escala. }\end{array}$ \\
\hline
\end{tabular}




\subsection{Fixações}

As funções que a fixação ferroviária deve desempenhar variam muito de acordo com o tipo de dormente e o sistema de fixação adotado. Segundo a AREMA (Manual for Railway Engineering, 2009), de forma genérica, as fixações devem ter as seguintes características, em maior ou menor grau:

a) manutenção da bitola da via;

b) transferir os esforços vertical, horizontal e longitudinal do trilho para o dormente;

c) atenuar as cargas e impactos gerados pelo tráfego;

d) prover isolamento elétrico;

e) proporcionar ao trilho uma inclinação em relação à vertical.

A Tabela 10, a seguir, resume as características que a fixação deve possuir, de acordo com o tipo de dormente utilizado:

Tabela 10: Função das Fixações de Acordo com o Tipo de Dormente

\begin{tabular}{c|ccccc}
\hline \multirow{2}{*}{$\begin{array}{c}\text { Tipo de } \\
\text { Dormente }\end{array}$} & $\begin{array}{c}\text { Manutenção da } \\
\text { Bitola }\end{array}$ & $\begin{array}{c}\text { Transferência } \\
\text { de Carga }\end{array}$ & $\begin{array}{c}\text { Inclinação } \\
\text { do Trilho }\end{array}$ & $\begin{array}{c}\text { Atenuação de } \\
\text { Impacto }\end{array}$ & $\begin{array}{c}\text { Isolamento } \\
\text { Elétrico }\end{array}$ \\
\hline Madeira & $\operatorname{Sim}$ & $\operatorname{Sim}$ & $\operatorname{Sim}$ & Não & Não \\
Concreto & $\operatorname{Sim}$ & $\operatorname{Sim}$ & Não & Sim & Sim \\
Aço & $\operatorname{Sim}$ & $\operatorname{Sim}$ & Não & Não & Sim/Não \\
\hline
\end{tabular}

FONTE: AREMA Manual for Railway Engineering, 2009 (adaptado pelo autor)

A AREMA (Manual for Railway Engineering, 2009) ainda estabelece exigências específicas que cada fixação deve obedecer, também em função do tipo de dormente:

a) Para o dormente de madeira:

i. Uso de placas de apoio do trilho sobre o dormente, no caso de fixações elásticas. 
b) Para o dormente de concreto:

i. Necessidade de isolamento elétrico em vias sinalizadas;

ii. Uso de palmilhas resilientes deve ser avaliado segundo a aplicação a qual a via se destina;

iii. Isoladores são normalmente usados para fixar e manter a bitola neste tipo de via.

c) Para o dormente de aço:

i. Palmilha resiliente e isoladores são necessários quando adotado dormente de aço em vias sinalizadas, a fim de proporcionar isolamento elétrico adequado.

Segundo a norma técnica ABNT NBR 11709 (2008), a opção pela escolha prévia do tipo de fixação a ser implantado na via influencia diretamente no projeto do dormente. Caso o tipo de fixação seja escolhido previamente, é necessário informar ao fabricante e projetista do dormente os seguintes dados:

a) Tipo, marca e modelo do conjunto de fixação;

b) Características dos componentes integrantes do conjunto de fixação.

Quando não há a definição prévia relativa à fixação, o projetista do dormente deve ser informado a respeito dos seguintes pontos:

a) Quais os tipos de conjunto de fixação aceitos;

b) Quais os tipos de palmilha de trilho aceitos;

c) Qualquer outra exigência preestabelecida pelo comprador/cliente relativa aos conjuntos de fixação dos trilhos.

Os tipos de fixação são divididos, basicamente, em dois tipos: rígidos ou elásticos. 


\subsubsection{Fixações Rígidas}

As fixações rígidas são utilizadas nos dormentes de madeira, porém seu uso hoje é bastante restrito, devido ao desenvolvimento de diversos tipos de fixações elásticas, que são mais eficientes em diversos aspectos, principalmente em relação ao amortecimento das vibrações produzidas pelo tráfego dos veículos.

Os tipos mais comuns de fixações rígidas são o prego de linha e o tirefond.

\subsubsection{Prego de Linha}

O prego de linha é o tipo de fixação mais simples existente. É geralmente de seção retangular, e é cravado a golpes de marreta em um furo previamente preparado no dormente - o que constitui um processo muito simples, porém com a desvantagem de ser manual.

Este material possui o inconveniente de ter a tendência de criar fissuras no dormente, em razão do método para sua instalação, além de oferecer pouca resistência ao arrancamento, de aproximadamente $2.200 \mathrm{~kg}$. Também é desfavorável o fato de o prego perder eficiência devido aos impactos e vibrações provenientes do trilho.

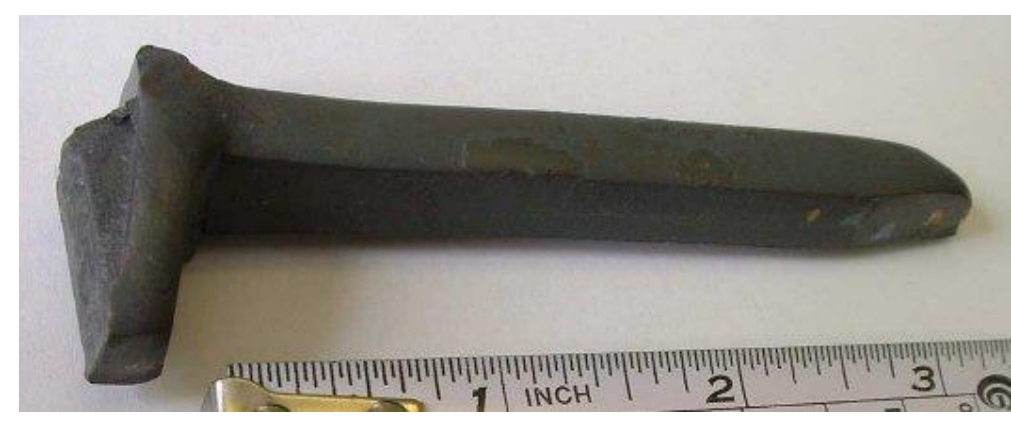

Figura 15: Prego de Linha

FONTE: $O$ autor (arquivo pessoal) 


\subsubsection{Tirefond}

O tirefond é um tipo de fixação superior ao prego de linha, pois, como é aparafusado, fica mais solidário à madeira do dormente, sacrifica menos as suas fibras e, conseqüentemente, oferece resistência ao arrancamento mais elevada, em torno de $7.000 \mathrm{~kg}$.

Um dos tipos fabricados atualmente é produzido pela Pandrol, e tem as seguintes especificações, que atendem às recomendações da AREMA:

a) Resistência à pressão de 65.000 psi (em torno de 448,2 MPa);

b) Revestimento resistente à corrosão;

c) Desenvolvido para uso combinado com a placa de apoio Pandrol ou com as placas de apoio padrão AREMA.

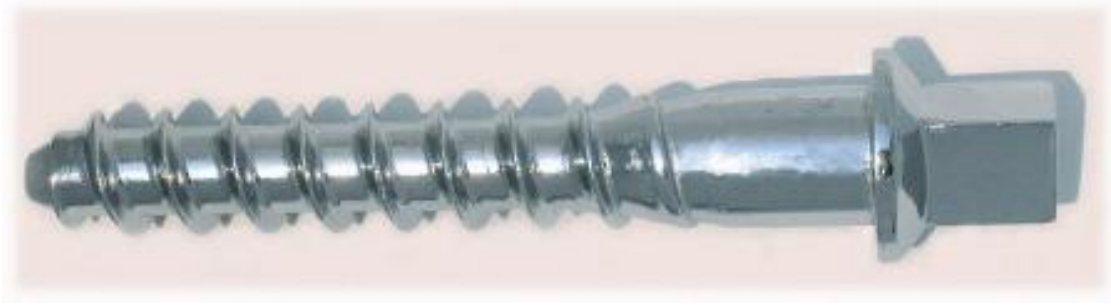

Figura 16: Tirefond

FONTE: Site Pandrol

\subsubsection{Fixações Elásticas}

As fixações elásticas são amplamente utilizadas nos mais variados tipos de ferrovia, desde linhas de metrô até vias para o transporte de mercadorias de grande peso específico, sendo essenciais especialmente nos dormentes de concreto.

Suas exigências de desempenho podem ter variações em razão da finalidade para a qual a via se destina, mas algumas características são gerais e devem ser sempre atendidas, conforme listado a seguir: 
a) Ter características elásticas capazes de conter os esforços longitudinais e transversais, além de amortecer os efeitos dinâmicos das cargas verticais, tanto para o caso de trilhos longos soldados como para o caso de trilhos conectados por talas de junção aparafusadas;

b) O projeto deve contemplar dois estágios de fixação distintos e independentes: fixação do trilho à placa de apoio e fixação da placa de apoio ao dormente.

A diversidade de materiais existentes para as fixações elásticas é elevada, e serão listados a seguir alguns dos principais componentes que atendem às exigências de ferrovias de transporte de carga e que estão presentes no mercado nacional.

\subsubsection{Fixação Aparafusada Dorbrás DB2}

Este tipo de fixação aparafusada foi desenvolvido pela empresa brasileira Dorbrás com o intuito de substituir as fixações RN (Figura 17), de origem francesa e cujo projeto data da década de 1940.

O objetivo desta fixação é melhorar a resposta aos esforços dos dormentes de concreto em curvas de pequeno raio e em vias onde atuam cargas pesadas, pois são situações onde as fixações RN tinham tendência a apresentar desgaste prematuro nas cavidades de apoio das molas de fixação. As fixações DB2 (Figura 18) também têm a vantagem de possuir melhor isolamento elétrico, maior força de aperto e maiores retencionamentos lateral e longitudinal. 


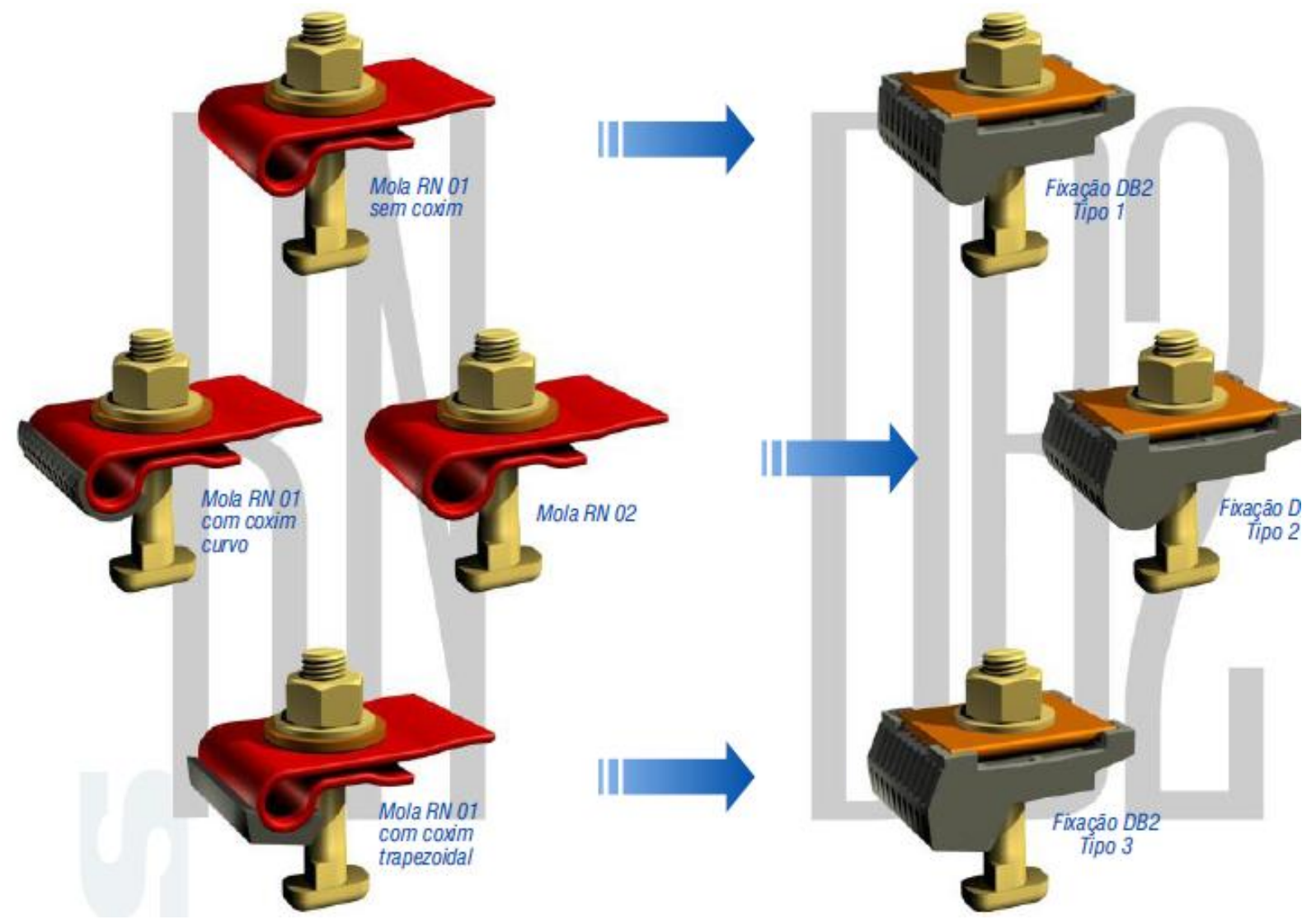

Figura 17: Comparação Fixação DB2 e Fixação RN

FONTE: Catálogo Dorbrás

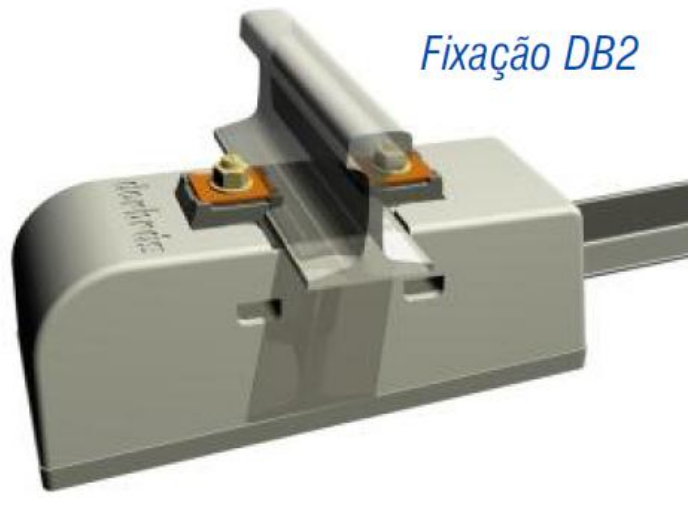

Figura 18: Fixação DB2 em um Dormente de Concreto Bi-Bloco

FONTE: Catálogo Dorbrás 


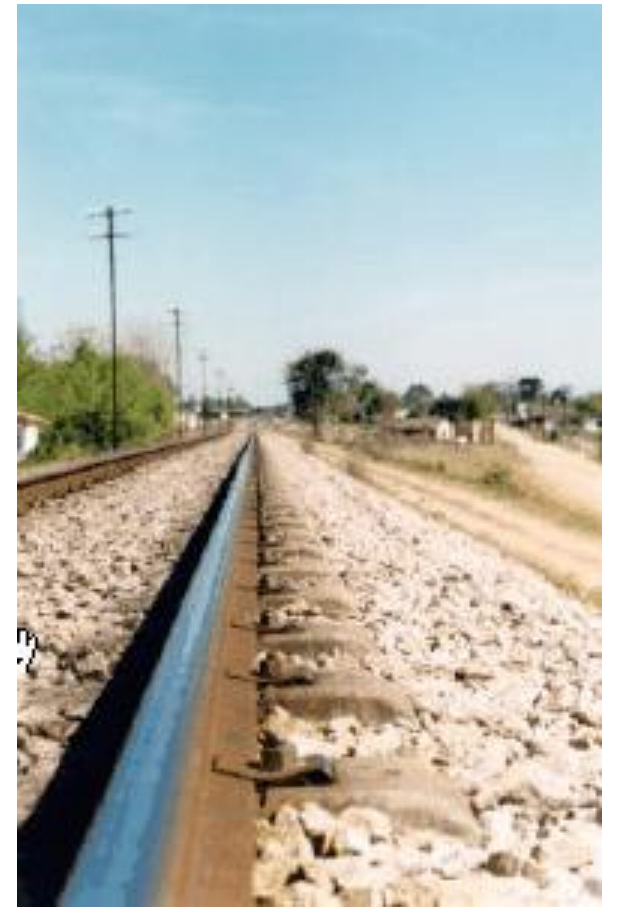

Figura 19: Fixação Aparafusada do tipo RN em linha operada pela ALL Logística FONTE: Catálogo Dorbrás

\subsubsection{Fixação Aparafusada Dorbrás S.75}

São fixações duplamente elásticas e isolantes de alto desempenho (Figura $20 \mathrm{e}$ Figura 21), compostas por calços isolantes de náilon de alta resistência à compressão e ao impacto, lâminas de mola dimensionadas para produzir elevada força de aperto e palmilhas de borracha padrão UIC (responsáveis pela atenuação de impacto e de vibrações de alta freqüência).

Suas principais características técnicas são as seguintes:

a) Não há necessidade de reaperto do parafuso após a montagem;

b) Alta capacidade de retenção longitudinal, superior a $18 \mathrm{kN}$ por assento do trilho;

c) Alta pressão vertical de contato para a fixação montada, superior a $34 \mathrm{kN}$ por assento do trilho, o que permite o permanente contato das fixações com o patim do trilho; 
d) Grande isolamento elétrico;

e) Componentes metálicos da fixação protegidos por revestimento anti-corrosivo.

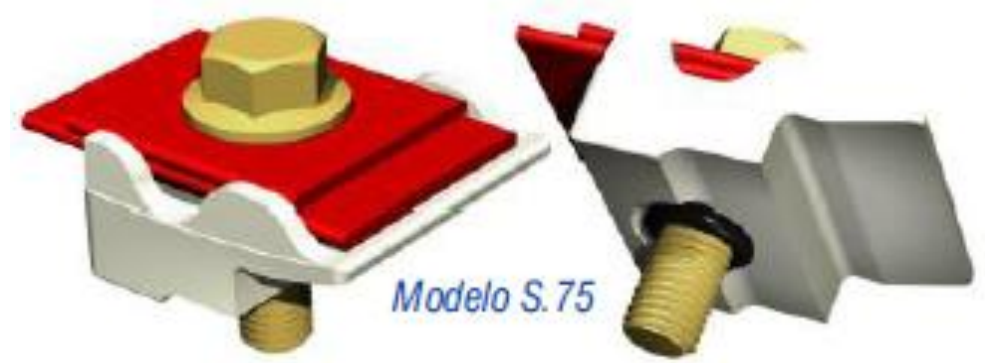

Figura 20: Modelo S.75

FONTE: Catálogo Dorbrás

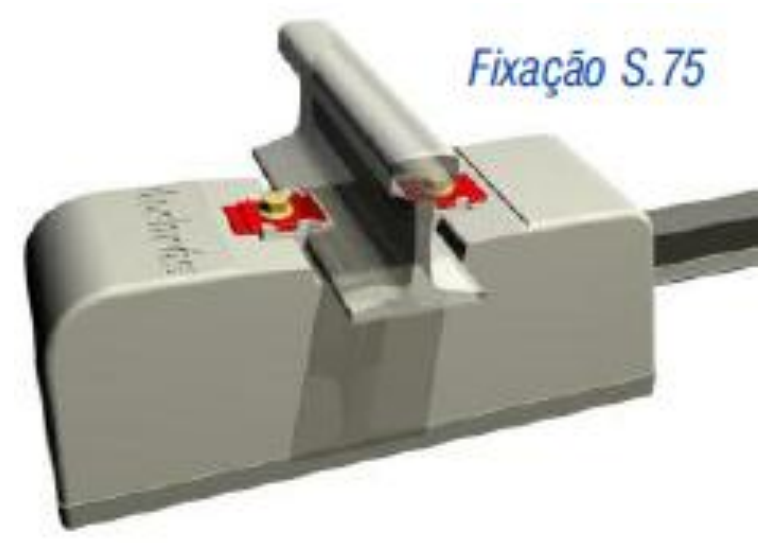

Figura 21: Fixação S.75 em Dormente de Concreto Bi-Bloco FONTE: Catálogo Dorbrás 


\subsubsection{Grampo Elástico Deenik}

O grampo Deenik foi desenvolvido no final da década de 1950 e pode ser utilizado tanto preso diretamente ao trilho, como combinado com o uso de placa de apoio sobre o dormente.

Normalmente, um fixador é pré-instalado no dormente e o grampo, posteriormente, é conectado a este fixador, fazendo a ligação entre o trilho e o dormente. Como este tipo de fixação não utiliza parafusos, teoricamente a manutenção nunca será necessária, já que não existe a necessidade de reaperto.

Atualmente, existe um modelo deste grampo que possui seção variável, o que contribui para a melhor distribuição dos esforços ao longo da peça, diminuindo sua concentração nas zonas de menor raio. Como conseqüências são obtidas as seguintes vantagens: maior elasticidade, prolongamento da vida útil e aumento na capacidade de absorver deformações, tanto na instalação como na operação.

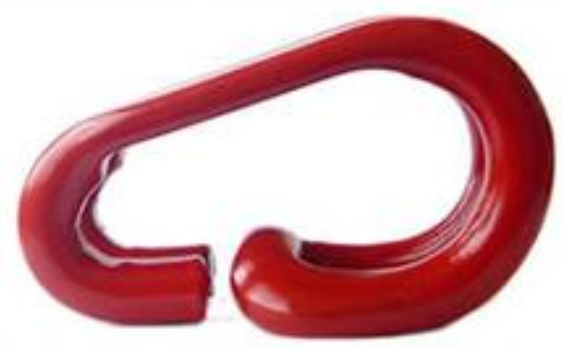

Figura 22: Grampo Deenik de Seção Variável FONTE: Catálogo IAT

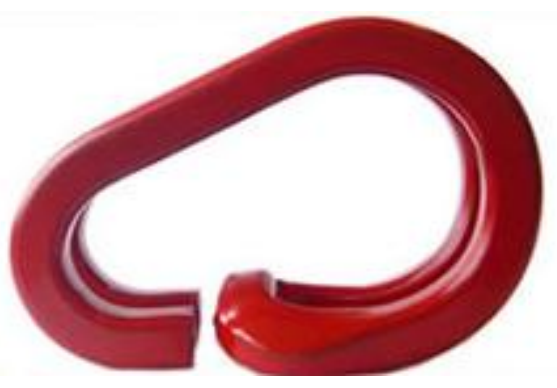

Figura 23: Grampo Deenik FONTE: Catálogo IAT 


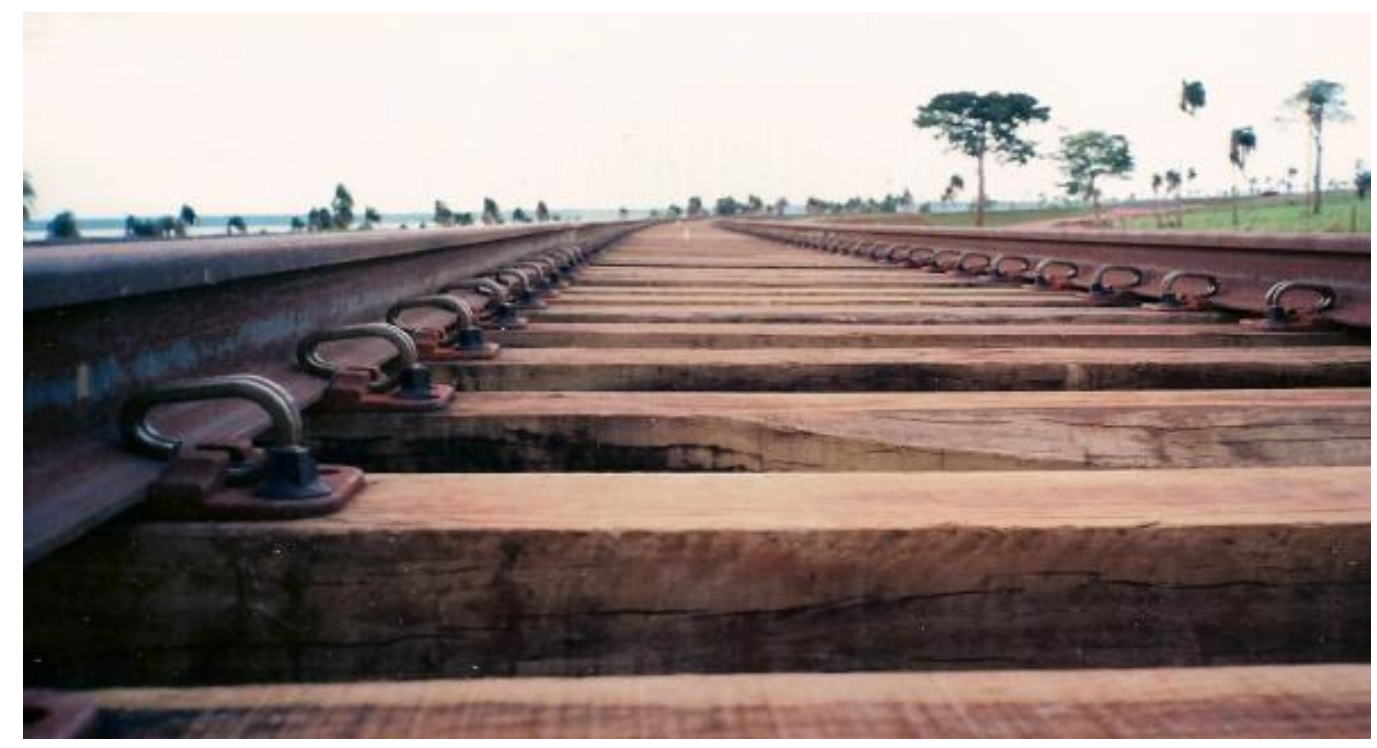

Figura 24: Aplicação do Grampo Deenik em na Ligação Ferroviária entre São Paulo e Mato Grosso do Sul - ALL Logística

FONTE: Memorial Fotográfico da Obra - FC Construções, 2009

\subsubsection{Grampo Elástico Pandrol FastClip}

Este tipo de grampo foi desenvolvido pela Pandrol em decorrência da necessidade das empresas operadoras de trens por um material de fixação de instalação rápida e de baixo custo, e que oferecesse baixo custo de manutenção. Todos os componentes do sistema de fixação são montados já no próprio trilho, e a instalação pode ser feita totalmente mecanizada.

Abaixo está representada a Tabela 11, com os principais dados técnicos da fixação em função do tipo de dormente. 
Tabela 11: Características da Fixação Pandrol FastClip

\begin{tabular}{lccc}
\hline \multirow{2}{*}{ Detalhes Técnicos } & \multicolumn{3}{c}{ Tipo de Dormente } \\
\cline { 2 - 4 } Raio Curva $<400 \mathrm{~m}$ & Sim & Sim & Sim \\
Raio Curva $>400 \mathrm{~m}$ & Sim & Sim & Sim \\
Carga por Eixo $<15 \mathrm{t}$ & Sim & Sim & Sim \\
Carga por Eixo $15 \mathrm{t}-25 \mathrm{t}$ & Sim & Sim & Sim \\
Carga por Eixo $>25 \mathrm{t}$ & Sim & - & Sim \\
Rigidez $>35 \mathrm{kN} / \mathrm{mm}$ & Sim & Sim & Sim \\
Aplicação em Via Eletrificada & Sim & Sim & Sim \\
\hline
\end{tabular}

FONTE: Catálogo Pandrol (adaptado pelo autor)

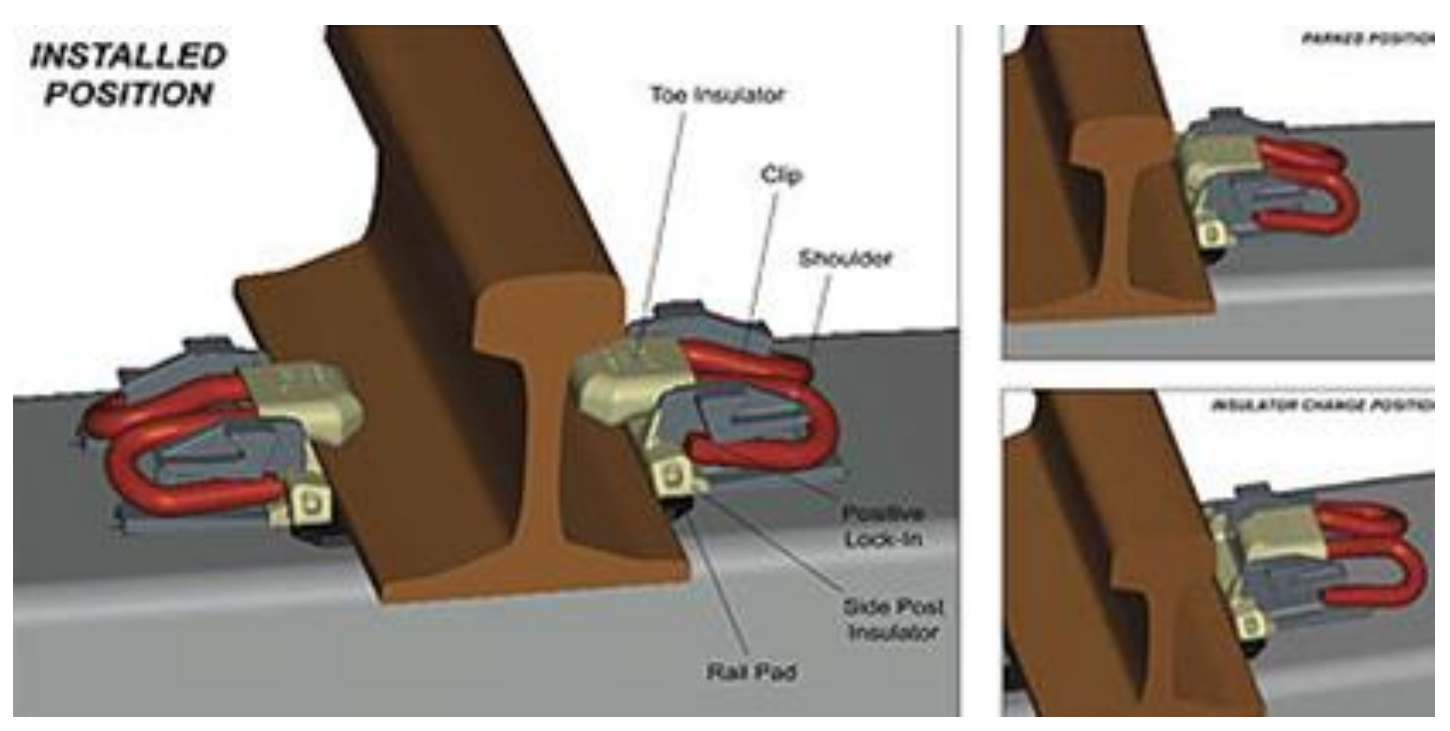

Figura 25: Grampo Pandrol FastClip

FONTE: Catálogo Pandrol 


\subsubsection{Grampo Elástico Pandrol eClip}

É um tipo de grampo fabricado com aço de mola, que se encaixa nos furos da placa de apoio, confeccionada especialmente para este tipo de componente. Este material é usado mundialmente e tem grande aceitação, devido às diversas vantagens que apresenta, tais como:

a) Composto por poucos componentes;

b) Elevada atenuação das vibrações;

c) Vida útil longa;

d) Pode ser usado em qualquer tipo de dormente e em vias sem lastro;

e) Pode ser instalado com uma trava anti-vandalismo, o que impede a remoção da fixação e também do dormente sem o uso de ferramenta apropriada;

f) Não necessita de manutenção;

Abaixo está representada a Tabela 12, com os principais dados técnicos da fixação em função do tipo de dormente. 
Tabela 12: Características da Fixação Pandrol eClip

\begin{tabular}{lcc}
\hline \multicolumn{1}{c}{ Detalhes Técnicos } & \multicolumn{2}{c}{ Tipo de Dormente } \\
\cline { 2 - 3 } Raio Curva $<400 \mathrm{~m}$ & Sim & Sim \\
Raio Curva $>400 \mathrm{~m}$ & Sim & Sim \\
Carga por Eixo $<15 \mathrm{t}$ & Sim & Sim \\
Carga por Eixo $15 \mathrm{t}-25 \mathrm{t}$ & Sim & Sim \\
Carga por Eixo $>25 \mathrm{t}$ & Sim & Sim \\
Rigidez $5-10 \mathrm{kN} / \mathrm{mm}$ & - & - \\
Rigidez $25-30 \mathrm{kN} / \mathrm{mm}$ & - & - \\
Rigidez $>35 \mathrm{kN} / \mathrm{mm}$ & Sim & Sim \\
Redução Ruído/Vibração & - & - \\
Aplicação em Via Eletrificada & Sim & Sim \\
\hline
\end{tabular}

FONTE: Catálogo Pandrol (adaptado pelo autor)

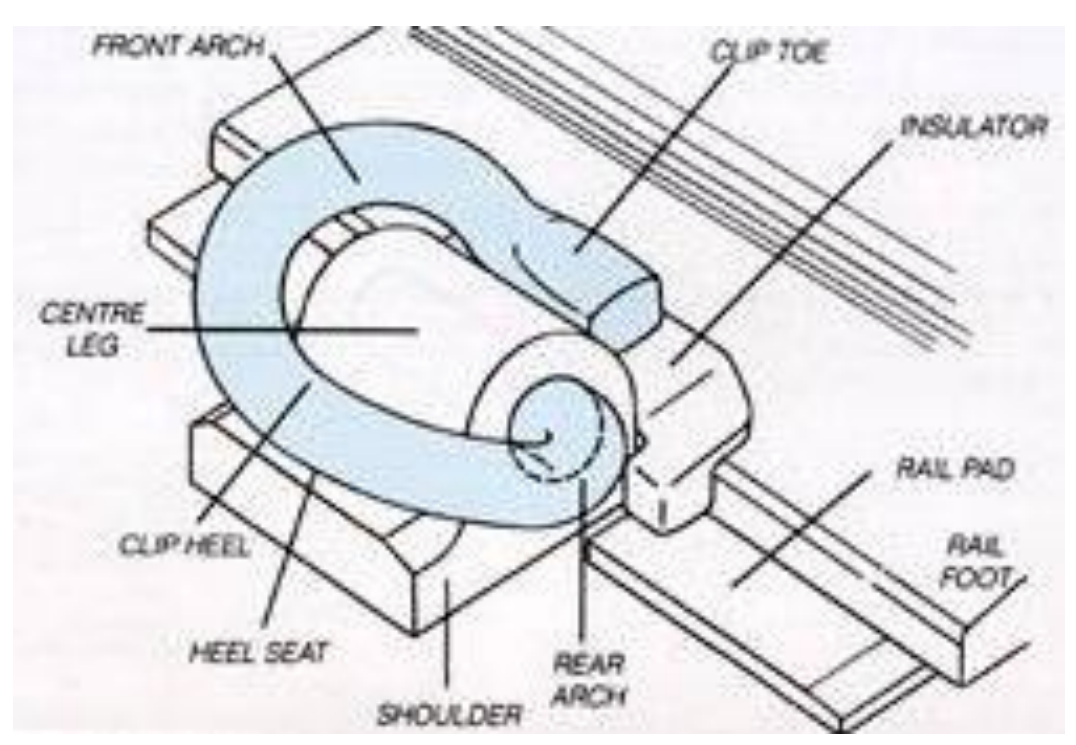

Figura 26: Grampo Pandrol eClip

FONTE: Catálogo Pandrol 


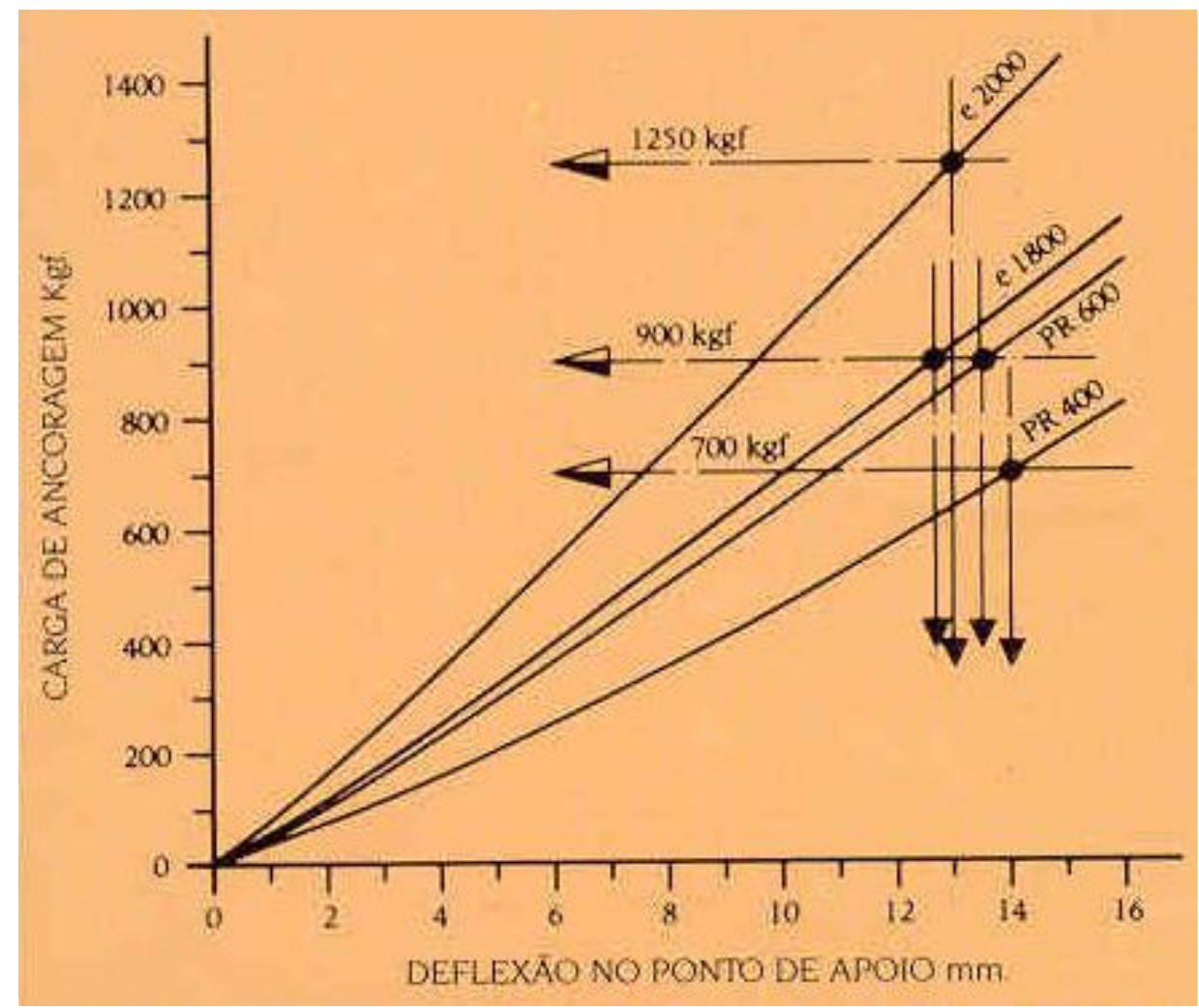

Figura 27: Características do Grampo Pandrol eClip

FONTE: Catálogo Pandrol

\subsubsection{Grampo Elástico Pandrol Safelok}

Este tipo de grampo foi desenvolvido para uso em vias submetidas a elevadas cargas de tráfego (superior a $40 \mathrm{t}$ por eixo), a fim de manter o alinhamento mesmo nas condições de solicitação mais severas.

O sistema de fixação pode ser pré-montado no dormente antes do transporte, e a instalação pode ser tanto manual como totalmente mecanizada.

Abaixo está representada a Tabela 13, com os principais dados técnicos da fixação, que pode ser instalada apenas em dormente de concreto. 
Tabela 13: Características da Fixação Pandrol Safelok

\begin{tabular}{lc}
\hline \multicolumn{1}{c}{ Detalhes Técnicos } & Concreto \\
\hline Raio Curva $<400 \mathrm{~m}$ & Sim \\
Raio Curva $>400 \mathrm{~m}$ & Sim \\
Carga por Eixo <15t & - \\
Carga por Eixo $15 \mathrm{t}-25 \mathrm{t}$ & - \\
Carga por Eixo $>25 \mathrm{t}$ & Sim \\
Rigidez $5-10 \mathrm{kN} / \mathrm{mm}$ & - \\
Rigidez 25 - $30 \mathrm{kN} / \mathrm{mm}$ & - \\
Rigidez $>35 \mathrm{kN} / \mathrm{mm}$ & Sim \\
Aplicação em Via Eletrificada & Sim \\
\hline
\end{tabular}

FONTE: Catálogo Pandrol (adaptado pelo autor)

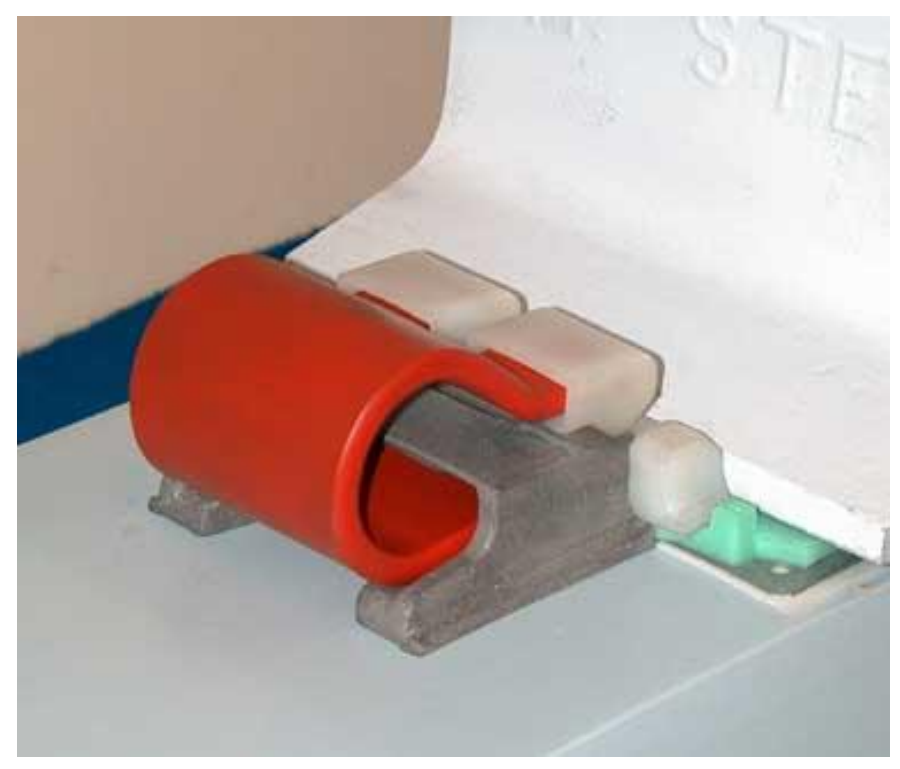

Figura 28: Grampo Pandrol Safelok FONTE: Catálogo Pandrol

As características principais dos grampos Pandrol (eClip, FastClip e Safelok) relatadas anteriormente podem ser resumidas na Tabela 14, a seguir: 
Tabela 14: Resumo das Características dos Grampos Pandrol

\begin{tabular}{cccc}
\hline Detalhes & \multicolumn{3}{c}{ Tipo de Dormente } \\
\cline { 2 - 4 } Técnicos & Concreto & Aço & Madeira \\
\hline $\begin{array}{c}\text { Raio Curva }< \\
400 \mathrm{~m}\end{array}$ & Todos & Fastclip & Todos \\
$\begin{array}{c}\text { Raio Curva }> \\
400 \mathrm{~m}\end{array}$ & Todos & Fastclip & Todos \\
$\begin{array}{c}\text { Carga por Eixo } \\
<15 \mathrm{t}\end{array}$ & Todos & Fastclip & Todos \\
$\begin{array}{c}\text { Carga por Eixo } \\
15 t-25 \mathrm{t}\end{array}$ & Todos & Fastclip & Todos \\
$\begin{array}{c}\text { Carga por Eixo } \\
>25 t\end{array}$ & FastClip/ & - & FastClip/ \\
$\begin{array}{c}\text { Carga por Eixo } \\
>40 \mathrm{t}\end{array}$ & Safelok & - & eClip \\
$\begin{array}{c}\text { Rigidez }>35 \\
\text { kN/mm }\end{array}$ & Todos & Todos & Todos \\
$\begin{array}{c}\text { Aplicação em } \\
\text { Via Eletrificada }\end{array}$ & Todos & Todos & Todos \\
\hline
\end{tabular}

FONTE: Catálogos Pandrol (adaptado pelo autor) 


\section{Modelo de Fluxograma para a Avaliação e Seleção dos Componentes da Grade Ferroviária}

Diante do grande volume de dados e informações que precisam ser pesquisados, analisados e inter-relacionados para que se consiga selecionar os trilhos, dormentes e fixações mais adequados para uma determinada ferrovia em projeto, é proposto no presente trabalho um modelo de fluxograma que visa ordenar os dados de entrada, orientar quanto aos requisitos de desempenho válidos para cada tipo de componente e, a partir das relações fixadas, apresentar os materiais aplicáveis ao caso em estudo com base nas opções disponíveis no mercado atual.

O modelo proposto, representado esquematicamente a seguir, não considera os fatores relacionados aos custos e à manutenção da via, mas sim apenas os condicionantes técnicos relativos ao projeto. Por isso, o modelo deve ser visto como uma ferramenta que busca nortear o profissional responsável pelo projeto em relação às etapas que devem ser seguidas para a correta seleção dos materiais da grade ferroviária e, principalmente, compilar em um único documento os dados sobre a variedade de trilhos, dormentes e fixações existentes no mercado atual, que muitas vezes são informações de difícil acesso ou pouco divulgadas. 


\section{DADOS DA VIA}

1) Bitola: $1,00 \mathrm{~m} / 1,435 \mathrm{~m} / 1,60 \mathrm{~m}$

2) Rampa Geométrica Máxima: $<1,5 \%$

3) Raio Horizontal Mínimo: $>300 \mathrm{~m}$

4) Velocidade Máxima de Projeto: $45 \mathrm{~km} / \mathrm{h}<\mathrm{V}<80 \mathrm{~km} / \mathrm{h}$
DADOS DO MATERIAL RODANTE

1) Carga por eixo [tf ou kN]

2) Trens Característicos:

- Tipo de Carga

- Tipo de Vagão (diâmetro da roda, distância entre eixos dos truques, distância entre eixos)

- № de Locomotivas e Vagões

- Carga Total Transportada [ton./ano]

\section{DIMENSIONAMENTO DO TRILHO}

Cálculo do Perfil de Trilho:

Método de SHAJUNIANZ

\section{ESCOLHA DO PERFIL}

Opções: TR-57 / UIC-60 / TR-68

Figura 29: Modelo do Fluxograma Proposto - Parte 1 (continua na página seguinte) 


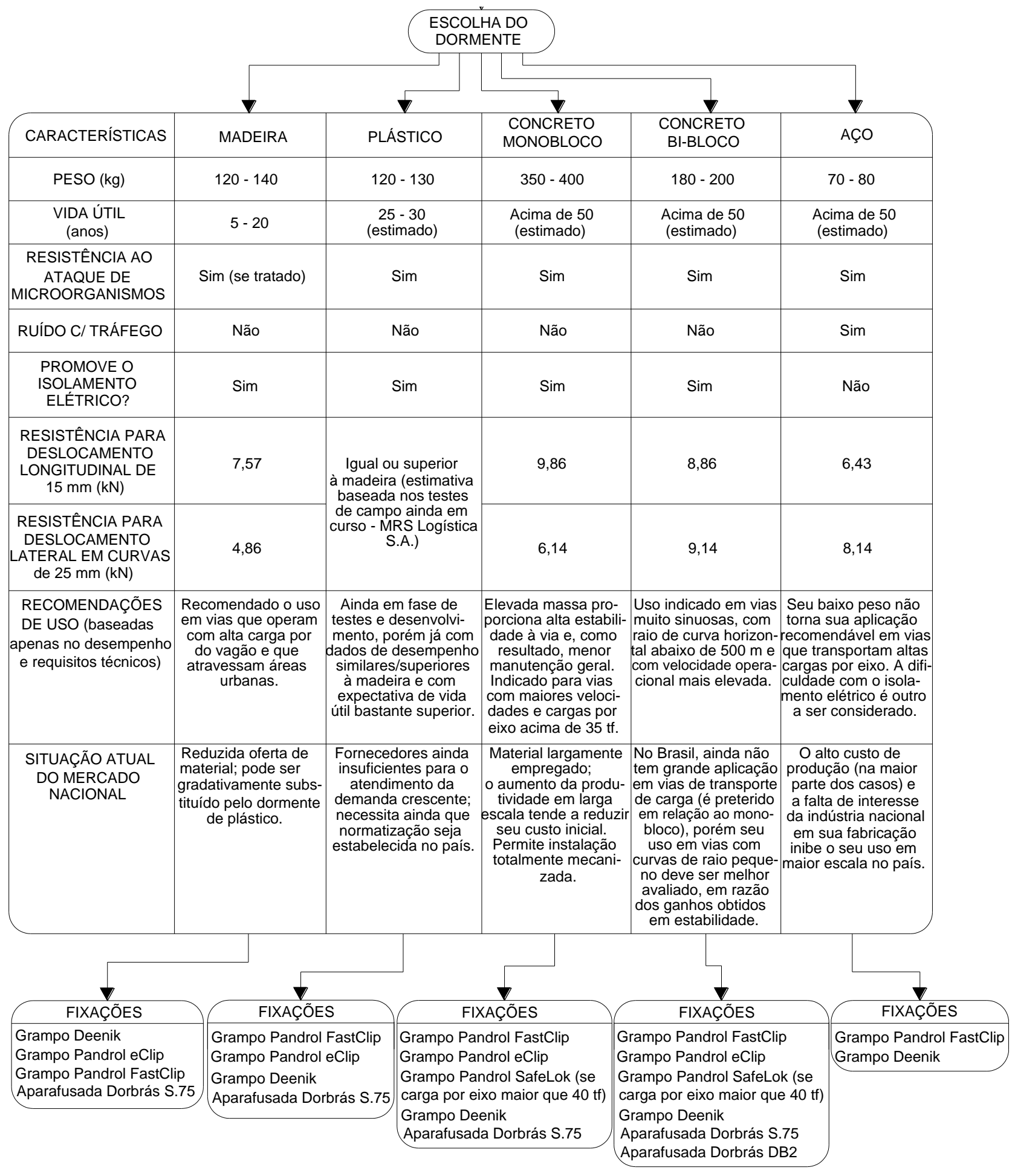

Figura 30: Modelo do Fluxograma Proposto - Parte 2 (continuação) 


\section{Estudo de Caso - Aplicação do Modelo de Fluxograma Proposto a uma Ferrovia em Projeto}

\subsection{Descrição do Trecho Estudado}

O estudo de caso compreende o trecho de ferrovia do projeto de segregação de linhas para o transporte de carga e de passageiros no trecho entre as Estações Manoel Feio e Suzano das Linhas E e F da Companhia Paulista de Trens Metropolitanos (CPTM-SP), que hoje são compartilhadas para transporte de passageiros e de carga (operado pela MRS Logística).

O intuito do projeto em questão é implantar vias exclusivas para o transporte de carga da MRS Logística, visando diminuir as restrições operacionais na região leste da Região Metropolitana de São Paulo, que tendem a se agravar com o aumento da demanda tanto do transporte de carga, como do transporte de passageiros.

O trecho a ser analisado está compreendido entre o Pátio de Eng. Manoel Feio e a estação Calmon Viana - correspondente à linha F da CPTM - com cerca de 8,2 km de extensão. O trecho restante da linha Tronco, entre Calmon Viana e a Variante Rio Grande da Serra, logo após a Estação Suzano, corresponde à linha E da CPTM, com cerca de $3 \mathrm{~km}$ de extensão. Tanto no primeiro quanto no segundo segmento, a via da MRS a ser implantada se localizará sempre ao lado esquerdo e paralelamente às vias existentes, no sentido Eng. Manoel Feio - Suzano. Após a estação de Suzano, está prevista uma obra de arte com $680 \mathrm{~m}$ de extensão para transposição da linha existente (Tronco) e conexão com a Variante de Rio Grande da Serra. 


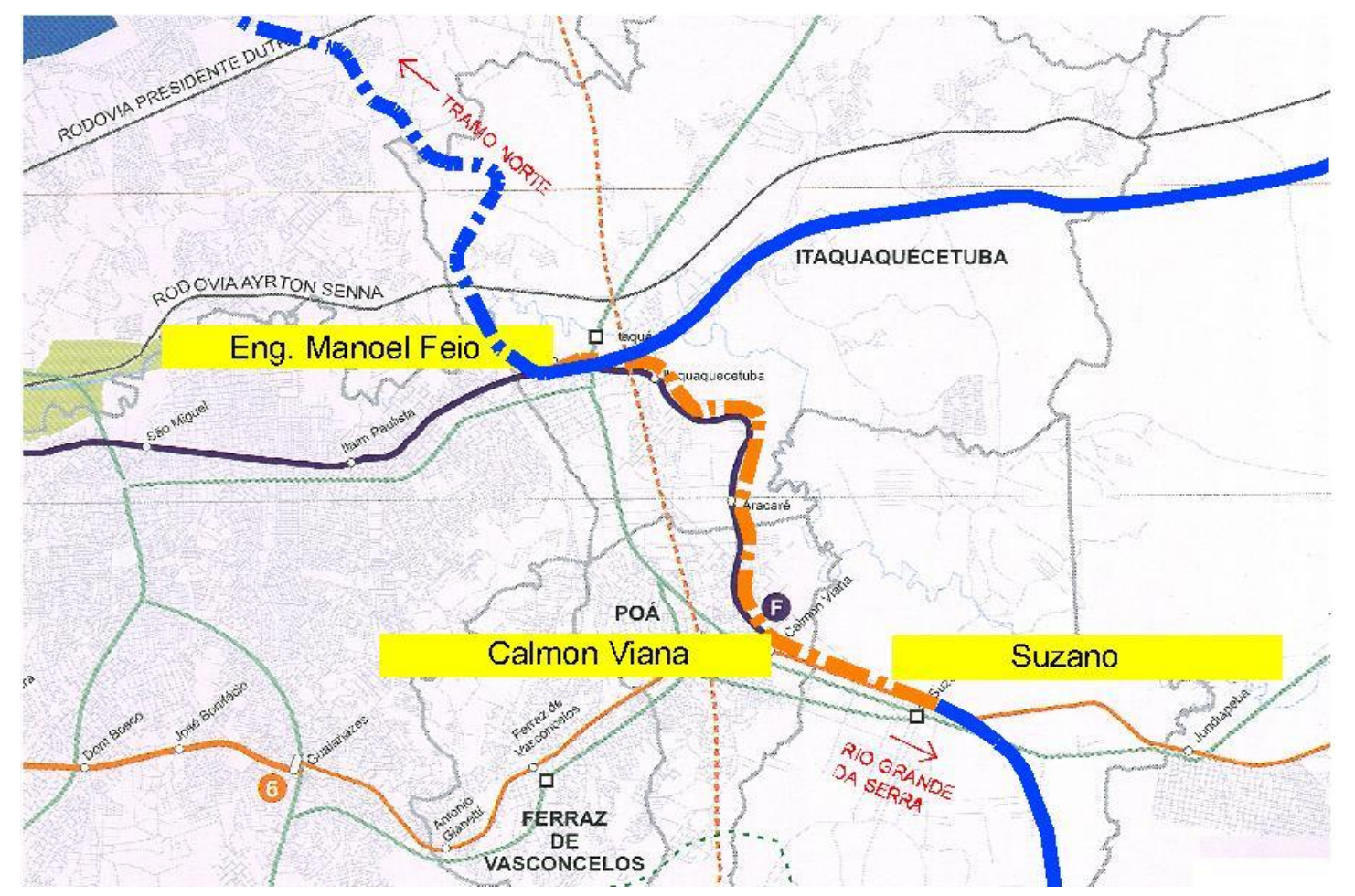

Figura 31: Localização do Empreendimento

FONTE: O autor

A MRS Logística S.A., que é a operadora dos trens nesta região, realiza nestas vias o transporte de diversos produtos, sendo os principais: contêineres, bauxita, cimento, minério de ferro, bobinas de aço, chapa de aço, celulose, madeira e peças de automóveis.

A extensão total da implantação das novas vias será de aproximadamente 11,2 km, todas com bitola de 1,600 m e entrevias variando de 4,00 a 7,20 m.

Após a implantação das novas vias, os trechos em questão terão a seção transversal com as seguintes configurações: 

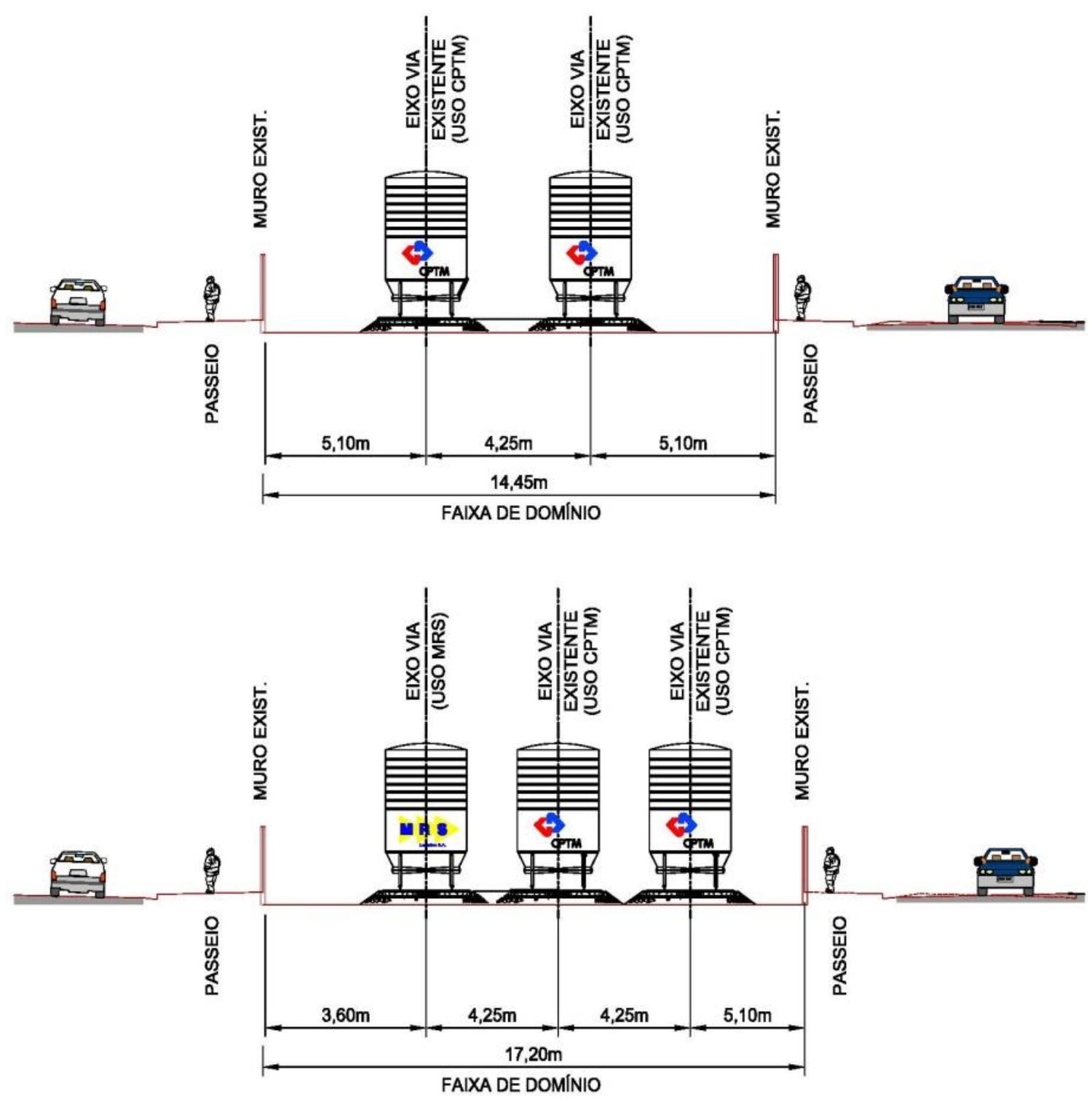

Figura 32: Trecho entre as Estações da CPTM Eng. Manoel Feio e Calmon Viana $(8,2 \mathrm{~km})$ FONTE: O autor 

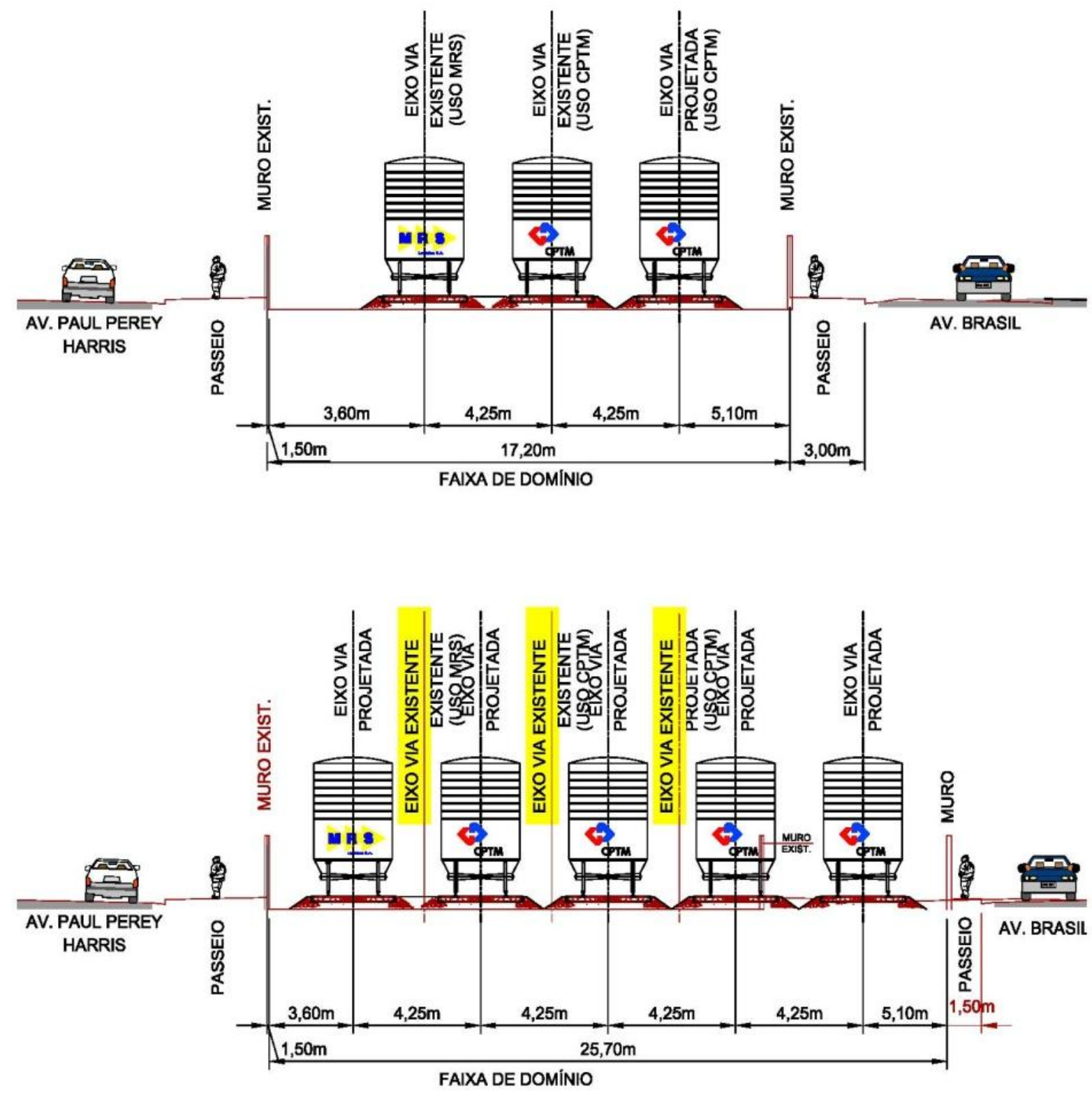

Figura 33: Trecho entre as Estações da CPTM Calmon Viana e Suzano (3km)

FONTE: O autor 


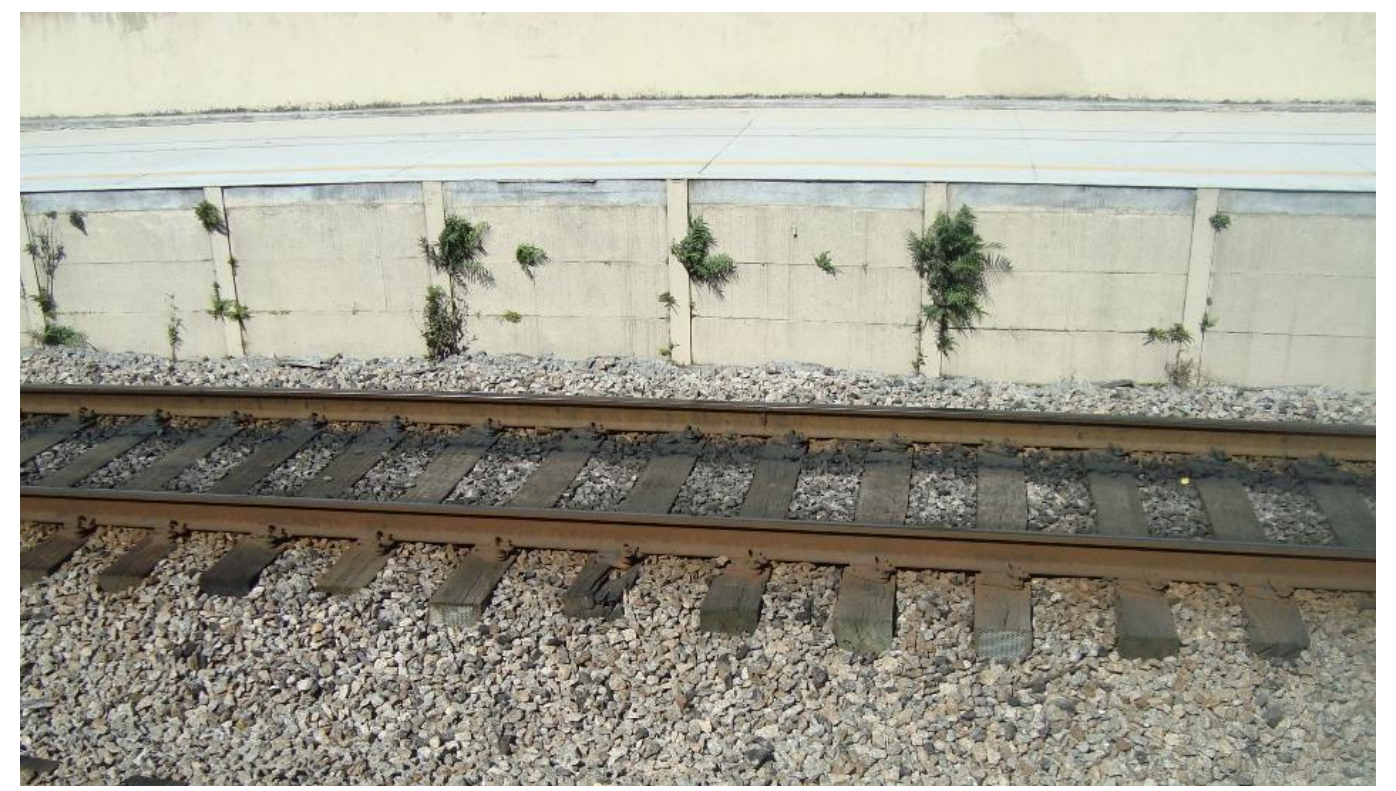

Figura 34: Via da CPTM Existente, com Dormentes de Madeira e Grampos Pandrol FONTE: O autor (arquivo pessoal)

\subsection{Objetivo do Estudo de Caso}

O objetivo do estudo de caso é aplicar o modelo de fluxograma na avaliação e seleção dos componentes que podem vir a ser implantados na composição da grade ferroviária da via em projeto. Assim, serão verificadas quais as possibilidades e limitações de aplicação desta ferramenta, bem como analisar se os resultados obtidos com o fluxograma são compatíveis com a escolha dos componentes que de fato serão implantados nas novas vias.

\subsection{Dados de Projeto da Ferrovia}

Os condicionantes do projeto da superestrutura da via permanente, definidos pela MRS Logística S.A., são:

a) Bitola: $1,600 \mathrm{~m}$;

b) Rampa Máxima: 1,25\%;

c) Raio de Curva Horizontal Mínimo: 300 m; 
i. Observação: o raio mínimo utilizado no projeto foi de $700 \mathrm{~m}$;

d) Velocidade Máxima de Projeto: $50 \mathrm{~km} / \mathrm{h}$;

e) Velocidade Máxima Operacional: $45 \mathrm{~km} / \mathrm{h}$;

f) Trens Característicos:

i. Minério de Ferro, com 132 vagões e 3 locomotivas $(11$ milhões de toneladas útil/ano) e carga por eixo do vagão de 32,5 tf;

ii. Bauxita, com 70 vagões e 2 locomotivas (2,3 milhões de toneladas útil/ano) e carga por eixo do vagão de 25,0 tf;

iii. Soja e Açúcar, com 85 vagões e 4 locomotivas ( 8,0 milhões de toneladas útil/ano) e carga por eixo do vagão de 22,0 tf.

g) Trilho: TR-68 (AREMA 136-RE);

h) Comprimento da barra do trilho: $240 \mathrm{~m}$ (trilho longo soldado);

i) Dormente: de madeira, com taxa de dormentação de 1850/km e dimensões de $2,80 \mathrm{~m} \times 0,17 \mathrm{~m} \times 0,24 \mathrm{~m}$;

j) Fixação Trilho/Dormente: Placa de apoio + grampo Pandrol;

k) Apoio Trilho/Dormente: Placa de apoio + grampo Pandrol;

I) Lastro: pedra britada, conforme norma da CPTM (Companhia Paulista de Trens Metropolitanos), com altura mínima sob os dormentes de $30 \mathrm{~cm}$;

m) Sub-lastro: conforme norma da CPTM (Companhia Paulista de Trens Metropolitanos), sendo camada constante com $20 \mathrm{~cm}$ de espessura. 


\subsection{Aplicação do Fluxograma Proposto ao Projeto das Novas Vias para o Transporte de Carga e Discussão dos Resultados Obtidos}

A partir da metodologia proposta no fluxograma desenvolvido, deve-se, inicialmente, selecionar o perfil de trilho que será implantado. O dimensionamento é feito a partir da aplicação dos dados de projeto da ferrovia (ver item 7.3) à Equação (1). Tem-se, portanto:

$$
\mathrm{W}=\mathrm{k} \times\left(1+\mathrm{T}^{0,25}\right) \times(1+0,012 \times \mathrm{V})^{0,6667} \times \mathrm{Q}_{\mathrm{e}^{0,6667}}
$$

Onde:

$\mathrm{k}=1,2$ (fator relativo ao vagão);

$\mathrm{T}=11 \times 10^{6}$ toneladas/ano (carregamento do maior trem característico estabelecido);

$\mathrm{V}=50 \mathrm{~km} / \mathrm{h}$;

$Q_{e}=32,5 \mathrm{tf}$ (carga por eixo relativa ao trem característico carregado com minério de ferro, representado pelo vagão GDT, conforme Tabela 2).

A aplicação da Equação (1) resulta em:

$\mathrm{W}=47,17 \mathrm{kgf} / \mathrm{m} \rightarrow$ Portanto, poderia ser adotado o perfil TR-50

Deve-se notar que, no cálculo efetuado acima, não foi estipulada uma projeção do crescimento anual do volume de carga transportado, e tampouco esta informação está presente nos dados do projeto fornecidos pela MRS Logística S.A. Evidentemente, seria um grande risco adotar o perfil do trilho TR-50 para esta via, baseado apenas no cálculo que considera o volume atual transportado. Dessa maneira, foram estabelecidos três cenários futuros que prevêem diferentes taxas de crescimento, para um mesmo horizonte de projeto fixado (25 anos), que resultaram nos seguintes valores para a tonelagem bruta anual: 
a) Cenário 1:

Taxa de crescimento anual de $2 \% \rightarrow \mathrm{T}=18,05 \times 10^{6}$ toneladas/ano

b) Cenário 2:

Taxa de crescimento anual de $5 \% \rightarrow \mathrm{T}=37,25 \times 10^{6}$ toneladas/ano

c) Cenário 3:

Taxa de crescimento anual de $8 \% \rightarrow \mathrm{T}=75,33 \times 10^{6}$ toneladas/ano

Aplicando novamente a Equação (1), agora para os novos valores da tonelagem bruta anual segundo os três cenários distintos, são obtidos os valores do peso linear do trilho, conforme abaixo:

a) Cenário 1:

$\mathrm{W}=51,18 \mathrm{kgf} / \mathrm{m} \rightarrow$ Perfil TR- 57

b) Cenário 2:

$W=58,02 \mathrm{kgf} / \mathrm{m} \rightarrow$ Perfil UIC-60 ou TR- 68

c) Cenário 3:

$\mathrm{W}=65,97 \mathrm{kgf} / \mathrm{m} \rightarrow$ Perfil TR- 68

Dado o acentuado crescimento anual registrado no Brasil para o transporte de carga por ferrovia (estimado em 13\% para 2011, em relação a 2010), não é exagero constatar que a previsão estimada pelo cenário 3 possa, de fato, tornar-se realidade dentro do horizonte de projeto estabelecido. Dessa forma, a escolha do perfil de trilho TR-68 mostra-se adequada para o projeto das novas vias, visto que proporciona uma margem de segurança confortável quanto ao atendimento à expectativa de aumento dos volumes transportados. Além disso, deve também ser levado em conta o fato de que a opção pelo emprego de um trilho com maior perfil resulta em um maior intervalo para a manutenção e troca do componente, já que levará mais tempo até que o limite máximo de desgaste do boleto seja atingido. Este 
fator é, particularmente, bastante atrativo para uma ferrovia de transporte de carga, pois representa menor quantidade de interrupções na operação ao longo de sua vida útil.

Tendo definido o perfil do trilho, a próxima etapa será a definição do tipo de dormente a ser implantado. Neste momento, ao se fazer uma análise mais superficial, pode-se acreditar que todas as opções disponíveis no fluxograma são aplicáveis à ferrovia em projeto. Porém, uma análise um pouco mais detalhada dos itens presentes na tabela comparativa do fluxograma já permite que algumas destas opções sejam eliminadas.

Primeiramente, a escolha pelo dormente de aço já pode ser descartada, uma vez que a dificuldade em prover um eficiente isolamento elétrico na nova via pode trazer problemas à operação, principalmente ao se levar em conta que os trens trafegarão em área urbana, onde a possibilidade de acidentes com usuários que entram na linha férrea é maior. Além disso, o baixo peso do dormente afeta muito a estabilidade da via, o que é bastante prejudicial em linhas destinadas ao transporte de carga.

Da mesma forma, a opção pelo dormente de concreto bi-bloco também pode ser eliminada, já que a principal vantagem de sua aplicação refere-se aos ganhos adicionais em estabilidade lateral, o que não é um fato relevante no projeto em questão, pois o menor raio de curva horizontal utilizado no projeto é de 700 metros (ou seja, em nenhum momento fica configurada uma situação de curva com raio considerado "pequeno") e a velocidade operacional é baixa no trecho analisado, em virtude novamente das composições trafegarem em área urbana.

Assim, passam a restar três opções de dormentes disponíveis na tabela comparativa do fluxograma. Por ainda ser uma peça que está em fase de teste de campo experimental, o dormente de plástico, embora já apresente alguns resultados promissores e desperte interesse em sua aplicação em maior escala, também deve ser descartado nesse momento (eventualmente, pode ser aplicado à via em larga escala no futuro, quando o conhecimento dos dados sobre seu desempenho e vida útil estiver mais consolidado). 
Com isso, a escolha recai sobre as duas opções restantes: madeira ou concreto monobloco. Neste ponto, percebe-se que não há qualquer impedimento ou limitação técnica que possa excluir a opção por um ou outro dormente, visto que ambos podem atender plenamente às exigências necessárias para que a nova via desempenhe suas funções com segurança, eficiência e confiabilidade. Com relação à escolha das fixações, as opções são diversas, mas aquelas listadas no fluxograma apresentam coerência em comparação à opção feita pelo grampo Pandrol eClip no projeto, podendo inclusive outros tipos de fixação serem aplicados sem resultar em perdas à ferrovia, tais como o grampo Deenik, por exemplo.

A impossibilidade de definição do tipo de dormente por meio da utilização do fluxograma proposto e de sua tabela comparativa mostra, claramente, que a avaliação restrita apenas aos condicionantes técnicos muitas vezes não é suficiente para que se consiga obter uma decisão a respeito de qual componente é o mais adequado, mesmo em uma avaliação prévia, o que representa uma limitação já esperada da aplicação desta ferramenta.

No caso do projeto das novas vias em questão, fatores como o custo inicial de implantação certamente tem um peso maior na opção feita pela operadora MRS Logística S. A., que decidiu pelo uso do dormente de madeira. É interessante ressaltar que o fato de as vias não pertencerem à empresa, mas sim serem resultado de uma concessão, também pode contribuir nesta decisão. Sob esta ótica, a implantação de dormentes de concreto monobloco, com elevada vida útil, pode não ser considerada vantajosa justamente porque o prazo concedido para exploração da referida malha poderia expirar muito antes que os benefícios da maior vida útil (e maior custo inicial de instalação) possam ser revertidos em ganhos de produtividade para a empresa. 


\section{Considerações Finais}

O presente trabalho apresentou inicialmente, a partir dos dados de fabricantes e de fornecedores, uma extensa relação que engloba os principais tipos de trilhos, dormentes e fixações presentes no mercado brasileiro e utilizados nas ferrovias de transporte de carga. Buscou-se também apresentar, de maneira breve e concisa, a relação das propriedades e características que estes materiais devem possuir, baseada nas mais recentes publicações técnicas nacionais e internacionais e em informações provenientes de algumas das maiores operadoras de ferrovias brasileiras.

Desta maneira, foi possível reunir em um único texto dados atualizados a respeito de uma grande variedade de componentes, principalmente os dormentes e fixações, contribuindo para que os profissionais envolvidos em projetos ferroviários possam ter ao seu alcance um material abrangente e atualizado a respeito deste tema.

O modelo de fluxograma desenvolvido buscou resumir o conjunto de informações relativo à variedade de componentes da grade ferroviária exposto no trabalho e apresentar os principais requisitos técnicos característicos de cada tipo de dormente, que devem ser considerados na etapa de concepção de um projeto de ferrovia destinada ao transporte de carga.

Entende-se que o banco de dados apresentado e o fluxograma proposto podem ser ferramentas úteis na etapa de concepção de novos projetos ferroviários, visto que apresentam de maneira clara e objetiva um conjunto de informações muito abrangente a respeito dos critérios técnicos e das opções de componentes disponíveis no mercado, fornecendo uma orientação inicial consistente ao profissional envolvido com projetos sobre os materiais que podem ser aplicados a uma ferrovia em estudo.

As informações referentes aos custos de implantação e de manutenção de cada tipo de componente da grade ferroviária pesquisado não foram consideradas na avaliação do estudo em questão, que buscou englobar apenas os aspectos técnicos. Isto resulta em uma limitação para a aplicação do fluxograma, pois não permite estabelecer a relação entre as despesas geradas (tanto na implantação como na 
manutenção) e os benefícios da escolha de determinado material, o que reforça ainda mais a orientação para que esta ferramenta seja utilizada principalmente em estudos iniciais de projeto, quando ainda não existe uma grande preocupação em avaliar os custos envolvidos.

A aplicação do fluxograma desenvolvido a um trecho de ferrovia em projeto, na Grande São Paulo, buscou verificar se a orientação fornecida por esta ferramenta quanto à escolha dos componentes é válida e se os resultados aos quais induz o projetista são coerentes com aquilo que, de fato, será instalado nas novas vias. Concluiu-se que o fluxograma, apesar de não abordar de maneira quantitativa os aspectos relacionados aos custos iniciais e de manutenção, contribui na tarefa de nortear o profissional responsável pelo projeto em relação a restringir as opções de componentes que podem ser escolhidos, auxiliando no processo de seleção dos materiais e na tomada de decisão.

Visando à continuidade do trabalho aqui apresentado, podem ser feitas as seguintes sugestões para estudos futuros:

a) Prosseguir o desenvolvimento do fluxograma proposto, englobando os fatores relativos aos custos iniciais e de manutenção de cada componente, de forma que a avaliação possa evoluir para um modelo técnico e também financeiro.

b) Avaliar os critérios de seleção e escolha das fixações elásticas, principalmente os grampos elásticos, pois comumente estas peças são escolhidas previamente (antes mesmo da escolha e do dimensionamento do dormente a ser utilizado), com base principalmente em seu custo inicial, manutenção e características de elasticidade. Neste estudo, propõe-se que os diversos tipos de fixações existentes sejam avaliados e comparados, tanto em relação ao atendimento às exigências de projeto, como em relação à sua manutenção, vida útil e métodos de instalação.

c) Elaborar um estudo que compare os dormentes de madeira e de plástico quanto aos aspectos de desempenho e de atendimento às exigências de projeto de ferrovias de carga. Grande parte das operadoras de carga nacional já possui o dormente de plástico instalado em vias-teste, onde eles 
são monitorados continuamente. A reunião e análise dos dados já existentes provenientes de cada concessionária a respeito de seus testes práticos e a sua comparação com os dados dos dormentes de madeira, já tão bem conhecidos por todos, seria de grande utilidade aos profissionais atuantes em projetos ferroviários, que disporiam de informações atualizadas e confiáveis relativas a este novo material, cujas propriedades ainda são tão pouco conhecidas e divulgadas. 


\section{Referências Bibliográficas}

ALIAS, J. Le Rail. Eyrolles. Paris, 1987.

ALIAS, J. Le Voie Ferrée. Eyrolles. Paris, 1977.

ALSTOM TRANSPORTE. Disponível em:

<www.transport.alstom.com/home/products_and_services/rail_infrastructure/tr ack_laying/30953.EN.php?languageld=EN\&dir=/home/products_and_services/r ail_infrastructure/track_laying/>. Acesso em 10 fev. 2011.

ALVES, G. K. A. Os Dormentes Ferroviários, seu Tratamento e o Meio Ambiente. Dissertação (Mestrado em Engenharia de Transportes) - Instituto Militar de Engenharia - IME. Rio de Janeiro, RJ, 2006.

AMSTED-MAXIOM. Disponível em: <www.amsted-maxion.com.br >. Acesso em 9 mai. 2011.

ANTF. Balanço do Transporte Ferroviário de Cargas, 2010. Associação Brasileira dos Transportadores Ferroviários. Disponível em: <www.antf.org.br>. Acesso em 23 jul. 2011.

AREMA. Manual for Railway Engineering - Volume 1 - Chapter 4 - Rail. American Railway Engineering and Maintenance-of-Way Association, USA, 2009.

AREMA. Manual for Railway Engineering - Volume 1 - Chapter 5 - Track. American Railway Engineering and Maintenance-of-Way Association, USA, 2009.

AREMA. "Manual for Railway Engineering - Volume 1 - Chapter 30 - Ties. American Railway Engineering and Maintenance-of-Way Association, USA, 2009.

Associação Brasileira de Normas Técnicas. NBR-6966. Dormente. Rio de Janeiro, 1997.

NBR-7511. Dormente de Madeira - Requisitos e Métodos de Ensaio. Rio de Janeiro, 2005. 
NBR-11709. Dormente de Concreto - Projeto, Materiais e Componentes. Rio de Janeiro, 2008.

_NBR-11824. Dormente de Aço. Rio de Janeiro, 1991.

_NBR-12398. Trilho "Vignole”. Rio de Janeiro, 1991.

_NBR-7649. Fixação Ferroviária. Rio de Janeiro, 1991.

_NBR-7650. Trilho. Rio de Janeiro, 1982.

BASTOS, P. S. dos S. Análise Experimental de Dormentes de Concreto Protendido Reforçados com Fibras de Aço. Dissertação (Doutorado em Engenharia de Estruturas) - Escola de Engenharia de São Carlos, Universidade de São Paulo. São Carlos, SP, 1999.

BRINA, H. Estradas de Ferro - Volume 1 - Via Permanente. Rio de Janeiro. Livros Técnicos e Científicos S.A., 1979.

CORREIA, L. F. de M. Estudo da Sensibilidade dos Parâmetros de Dimensionamento de uma Via Férrea Submetida às Deformações Verticais. Dissertação (Mestrado em Engenharia de Transportes) - Universidade Estadual de Campinas. Campinas, SP, 2007.

CBTU. Especificação de Material - Dormente de Madeira. Companhia Brasileira de Trens Urbanos. Rio de Janeiro, RJ, 2002.

DORBRÁS Dormentes e Fixações. Disponível em: <www.dorbras.com.br>. Acesso em 7 jun. 2011.

ESVELD, C. Modern Railway Track. Germany. MRT - Productions, 1989.

FARIA, A. S. Utilização de Materiais Reciclados na Fabricação de Dormentes Ferroviários. Rio de Janeiro, RJ, 2006. 
FC CONSTRUÇÕES. Memorial Fotográfico da Obra - Ligação Ferroviária entre São Paulo e Mato Grosso do Sul. Disponível em: <www.fcconstrucoes.com.br/obras>. Acesso em 13 jul. 2010.

GARCÍA LOMAS Y COSSÍO, J. Tratado de Explotación de Ferrocarriles. Madri. Publicaciones de La Escuela Especial de Ingenieros de Caminos, Canales y Puertos, 1952.

HAY, W. W. Railroad Engineering. 2. Ed. New York. John Wiley \& Sons, 1982.

HIDREMEC. Disponível em: <www.hidremec.com>. Acesso em 08 jun. 2010.

IAT. Disponível em: <www.iatltda.com.br/deenik.htm>. Acesso em 2 jul. 2010.

MRS LOGÍSTICA S.A. Dados obtidos a partir de contato direto com a empresa. São Paulo, SP, 2011.

OLIVEROS RIVES, F., A. Lopez Pita e M. J. Megia Puente. Tratado de Ferrocarriles - Via. Madri. Rueda, 1977.

PANDROL. Disponível em: <www.pandrol.com>. Acesso em 21 nov. 2010.

PAIVA, C. E. L. Superestrutura Ferroviária. 2. Ed. Universidade Estadual de Campinas. Campinas, SP, 1999.

PFEIL, W. Estruturas de Madeira. Ed. 5. Rio de Janeiro, RJ. Livros Técnicos e Científicos Editora S.A.,1994.

PLASSER \& THEUER. Disponível em: <www.plassertheurer.at/index_en.htm>. Acesso em 15 ago. 2011.

PORTO, T. G. PTR 2501 - Ferrovias - Notas de Aula. Escola Politécnica da Universidade de São Paulo - Departamento de Engenharia de Transportes. São Paulo, SP, 2005.

QUEIROZ, R. C. Estudo Experimental das Resistências Horizontais e Verticais da Via Permanente Ferroviária com Dormentes de Concreto Protendido 
Monobloco, de Concreto Bi-bloco, de Aço e de Madeira. In: 19 Congresso Brasileiro do Concreto - 19ํㅡ. CBC. Bento Gonçalves, RS, 2007.

QUEIROZ, R. C., Macari, E. J. Method for Estimating Railroad Track Settlements Due to Dynamic Traffic Loads. In: Proceedings of the $16^{\text {th }}$ International Conference on soil Mechanics and Geotechnical Engineering. Millpress Science Publishers. Osaka, Japan, 2005.

SALLES, A. C. N. de. Emissões de Gases do Efeito Estufa dos Dormentes de Ferrovia de Madeira Natural e de Madeira Plástica no Brasil e na Alemanha com Base em seus Ciclos de Vida. Tese (Doutorado em Planejamento Energético) COPPE - Universidade Federal do Rio de Janeiro. Rio de Janeiro, RJ, 2009.

SCHRAMM, G. Permanent Way Technique and Permanent Way Economy. 1. ed. Otto Elsner Verlagsgesellschaft Darmstadt, 1961.

SEMPREBONE, P. S. Desgaste em Trilhos Ferroviários - Um Estudo Teórico. Dissertação (Mestrado em Engenharia de Transportes) - Universidade Estadual de Campinas. Campinas, SP, 2005.

SPADA, J. L. G. Uma Abordagem de Mecânica dos Pavimentos Aplicada ao Entendimento do Mecanismo de Comportamento Tensão-Deformação da Via Férrea. Tese (Doutorado em Engenharia de Transportes) - COPPE - Universidade Federal do Rio de Janeiro. Rio de Janeiro, RJ, 2003.

SOARES, L. Dormentes de Plástico na MRS Logística - Modos de Falha e Soluções. In: III Encontro de Ferrovias da ANTF - Sessão Técnica - Via Permanente - Associação Brasileira dos Transportadores Ferroviários. Juiz de Fora, MG, 2011.

STOPATTO, S. Via Permanente Ferroviária: Conceitos e Aplicações. São Paulo. Editora da Universidade de São Paulo, 1987.

VALEC Engenharia, Construções e Ferrovias S.A. Especificações de Projeto Projeto de Superestrutura. Rio de Janeiro, RJ, 2009. 
WEBB, W. L. Construção de Estradas de Ferro: Teoria e Prática. Rio de Janeiro. Casa do Estudante do Brasil, 1951.

WISEWOOD Dormentes de Madeira Plástica. Disponível em: <www.wisewood.com.br>. Acesso em 10 out. 2011. 